\title{
Petrographic Characterization of Raw Material Sources at Oldupai Gorge, Tanzania
}

\begin{abstract}
Julien Favreau ${ }^{1 *}$, María Soto ${ }^{1}$, Rajeev Nair ${ }^{2}$, Pastory M. Bushozi ${ }^{3}$, Siobhán Clarke ${ }^{1}$, Christopher L. DeBuhr', Paul R. Durkin ${ }^{4}$, Stephen M. Hubbard ${ }^{2}$, Jamie Inwood ${ }^{1}$, Makarius Itambu ${ }^{1,3}$, Fergus Larter ${ }^{1}$, Patrick Lee ${ }^{5}$, Robert A. Marr ${ }^{2}$, Aloyce Mwambwiga ${ }^{1,6}$, Robert Patalano ${ }^{1}$, Laura Tucker ${ }^{1}$ and Julio Mercader ${ }^{1,7 *}$

${ }^{1}$ Department of Anthropology and Archaeology, University of Calgary, Calgary, AB, Canada, ${ }^{2}$ Department of Geoscience, University of Calgary, Calgary, AB, Canada, ${ }^{3}$ Department of Archaeology and Heritage Studies, University of Dar es Salaam, Dar es Salaam, Tanzania, ${ }^{4}$ Department of Geological Sciences, University of Manitoba, Winnipeg, MB, Canada, ${ }^{5}$ Department of Anthropology, University of Toronto, Toronto, ON, Canada, ${ }^{6}$ National Natural History Museum, Arusha, Tanzania, ' Department of Archaeology, Max Planck Institute for the Science of Human History, Jena, Germany
\end{abstract}

\section{OPEN ACCESS}

Edited by:

Daniel Nývlt,

Masaryk University, Czechia

Reviewed by:

Cynthia M. Fadem,

Earlham College, United States Nadia Solovieva,

University College London, United Kingdom

*Correspondence: Julien Favreau

jfavreau@ucalgary.ca Julio Mercader mercader@shh.mpg.de

Specialty section:

This article was submitted to Quaternary Science, Geomorphology and Paleoenvironment, a section of the journal Frontiers in Earth Science

Received: 01 October 2019 Accepted: 28 April 2020

Published: 28 May 2020

Citation:

Favreau J, Soto M, Nair $R$ Bushozi PM, Clarke S, DeBuhr CL, Durkin PR, Hubbard SM, Inwood J, Itambu M, Larter F, Lee P, Marr RA, Mwambwiga A, Patalano R, Tucker L and Mercader J (2020) Petrographic

Characterization of Raw Material Sources at Oldupai Gorge, Tanzania.

Front. Earth Sci. 8:158. doi: 10.3389/feart.2020.00158
Oldupai Gorge is located within the Ngorongoro Conservation Area, a UNESCO World Heritage Site in northern Tanzania along the western margin of the East African Rift System. Oldupai's sedimentary record contains inter-stratified stone tool industries associated with the Earlier, Middle, and Later Stone Age. While diachronic technological change is perceptible, the totality of locally available rocks remained largely unchanged through time. Here, thin section petrography, Scanning Electron Microscopy-Energy Dispersive X-Ray Spectroscopy, and Electron Probe Micro Analysis were employed to characterize source lithologies in the Oldupai region. One of our goals was to determine if outcrops have rock types with unique mineral assemblages amenable for sourcing lithic artifacts. Petrographic analysis of 62 lithologic samples collected in primary and secondary positions reveal discriminatory differences. More precisely, five outcrops have quartzites with unique mineral assemblages, five outcrops have meta-granites with unique mineral assemblages, Engelosin phonolite samples are texturally and mineralogically unique, and magmatic samples recovered in secondary position may be sourced to their volcanic center. Our results demonstrate it is feasible to discriminate source materials using mineralogy, which implies that sourcing lithic artifacts is possible. For proof of concept, we assign the source/s of previously described fuchsitic quartzite artifacts from three archaeological sites at Oldupai to two nearby outcrops. Additional archaeological testing will allow researchers to glean new understandings of hominin behavior and stone procurement in the Oldupai paleobasin.

Keywords: petrography, reference collection, raw materials, sourcing, Oldupai Gorge

\section{INTRODUCTION}

Rocks used for artifact manufacture are alternatively known as lithic raw materials and occur as mineral aggregates of igneous, metamorphic, and sedimentary origin that are nonrenewable and spatially exhaustible over a non-geological timeframe (Kyara, 1996). Raw material characterization and sourcing through comparative study of geological specimens and artifacts 
(Weigand et al., 1977; Shotton and Hendry, 1979) can provide insights into stone selection and procurement strategies (Stout et al., 2005), transportation costs (Kyara, 1999), technological façonnage (Mason and Aigner, 1987), functional suitability (Ebright, 1987), anthropogenic usage (Courtenay et al., 2019), landuse behavior (Tactikos, 2005), population movements (Reimer, 2018), and social networks of trade and exchange (Lebo and Johnson, 2007). By extension, inferences may be drawn on technological, economic, ritual, and political systems in a variety of archaeological contexts (e.g., Renfrew, 1975; Flannery, 1976; Sidrys, 1976).

In this study, we characterize a range of lithologies that were available to hominins at Oldupai Gorge using a combination of thin section petrography, Scanning Electron Microscopy-Energy Dispersive X-Ray Spectroscopy (SEM-EDS), and Electron Probe Micro Analysis (EPMA). One of our goals was to determine the feasibility of sourcing lithic artifacts based on their mineralogy (cf. Soto et al., 2020a). Rock samples were collected in primary and secondary positions from 10 outcrops within the greater Oldupai region. Sixty-two samples including quartzites, meta-granites, feldspars, amphibolites, schists, granofels, phonolites, nephelinites, and basalts were studied using a polarizing microscope. Ten samples were subsequently analyzed using SEM-EDS and EPMA to complement petrographic observations.

We show that several outcrops near Oldupai Gorge have lithologies that can be identified by a unique combination of minerals which implies that sourcing lithic artifacts based on mineralogy is a viable technique. This is evidenced by the similarity of rock specimens from the Naibor Soit Kubwa and Naibor Soit Ndogo outcrops to previously described Oldowan and Acheulean quartzite artifacts from three archaeological sites. Our results not only establish the merit of further archaeological testing scaffolded by additional characterization efforts, but also contribute to the growing body of work which shows that quartzitic outcrops can be differentiated from each other despite their assumed homogeneity on a regional scale (Ebright, 1987; Stross et al., 1988; Pitblado et al., 2008, 2013; Blomme et al., 2012; Veldeman et al., 2012; Cnudde et al., 2013; Dalpra and Pitblado, 2016; Soto et al., 2020a,b). Our study will serve as a referential framework for future researchers to establish new links between the lithoscape and hominin raw material exploitation at Oldupai Gorge.

\section{OLDUPAI GORGE, TANZANIA}

\section{Geological Setting}

Oldupai Gorge is located on the boundary between the Tanzania Craton to the west and the Mozambique Belt to the east (Figure 1a). The Tanzania Craton is composed of Archean (4.0-2.5 Ga) low to medium grade metamorphic and igneous rocks including greenstones, granite gneisses, and quartzites. The Neoproterozoic Mozambique Belt comprises more deformed rocks dominated by quartzites, schists, and granites. Surface exposures of the Mozambique Belt include the Gol Mountains in north-central Tanzania (Cahen and Snelling, 1966; Cahen et al., 1984; Dawson, 2008; Scoon, 2018), and the metamorphic outcrops to the south near Oldupai Gorge (Figures 1a,b) (Hay, 1976).

Variably overlying the basement rocks of the Tanzania Craton and the Mozambique Belt and obscuring their contacts are volcanic rocks of the Ngorongoro Volcanic Highlands $(\mathrm{NVH})$ associated with the East African Rift System, which is an active intra-continental extension zone (Figures 1a,b). Rifting commenced in the Eocene and resulted in extensive volcanism that is still active today. Oldupai Gorge is situated in the North Tanzania Divergence Zone, to the northwest of the NVH (Figure 1a) and borders the westernmost faults of the Gregory Rift system (Baker et al., 1972; Dawson, 1992). The NVH is a mostly inactive group of volcanoes centered around the Ngorongoro Caldera. The catchment of the Oldupai paleobasin include five volcanic centers of the NVH: (1) Sadiman (4.63-3.5 Ma; 2,870 m.a.s.l.) (foidite, ijolite, nephelinite, phonolite, phonolitic tuff, and tephrite) (Hay, 1976; Mollel and Swisher, 2012; Zaitsev et al., 2012); (2) Engelosin (3-2.7 Ma; 1,648 m.a.s.l.) (phonolite and phonolitic breccia) (Hay, 1976; Mollel and Swisher, 2012); (3) Lemagrut (2.4-2.2 Ma; 3,135 m.a.s.l.) (basalt, benmorite, hawaiite, ignimbrite, and mugearite) (Mollel and Swisher, 2012); (4) Ngorongoro (2.252.01 Ma; 1,700-2,380 m.a.s.l.) (agglomerate, basalt, ignimbrite, rhyolite, trachyandesite, trachydacite, and trachyte) (Pickering, 1965; Mollel, 2002; McHenry et al., 2008; Mollel et al., 2008; Mollel and Swisher, 2012); and (5) Olmoti (2.01-1.80 Ma; 3,101 m.a.s.l.) (basalt, ignimbrite, trachyandesite, and trachyte) (Pickering, 1964, 1965; Hay, 1976; Manega, 1993; Mollel, 2002; McHenry et al., 2008; Mollel et al., 2009; Mollel and Swisher, 2012) (Figure 1b).

The Main and Side Gorge cut into the basement rocks of Eastern Serengeti Plains and provide good exposures of the stratigraphy. During the Early Pleistocene, Oldupai was an endorheic, rift-shoulder sedimentary basin that hosted a saline alkaline lake fed by stream networks from the NVH to the west, and characterized by abruptly rising metamorphic inselbergs associated with the Mozambique Belt (Hay, 1976; McHenry et al., 2008). The post-Ngorongoro stratigraphy exposed in the gorge (Oldupai Group) overlies a basal basalt unit in the east and an ignimbrite in the west associated with the final eruption from Ngorongoro (Hay, 1976; McHenry et al., 2008; Deino, 2012). As volcanic activity subsided, sediments were delivered to the basin from alluvial fans composed of pyroclasts to the east and fluvial channels from the west (Hay, 1976; Ashley and Hay, 2002). Deposition occurred in a variety of environments, including fluvial channels, floodplain, and lacustrine settings (Hay, 1976). The Oldupai Group, which attains a maximum thickness of $\sim 100 \mathrm{~m}$, is divided into seven units (Bed I-IV, Masek, Ndutu, and Naisiusiu) (Hay, 1976; Scoon, 2018) which preserve evidence of hominin activities. While variations in drainage patterns and resulting sedimentation altered Oldupai's paleoecology, the paleobasin was occupied by a host of hominin species where they procured raw materials from nearby outcrops to manufacture stone tools for a variety of daily tasks (Leakey, 1971; Mora and de la Torre, 2005; Diez-Martín et al., 2009, 2010; Yravedra et al., 2017). 

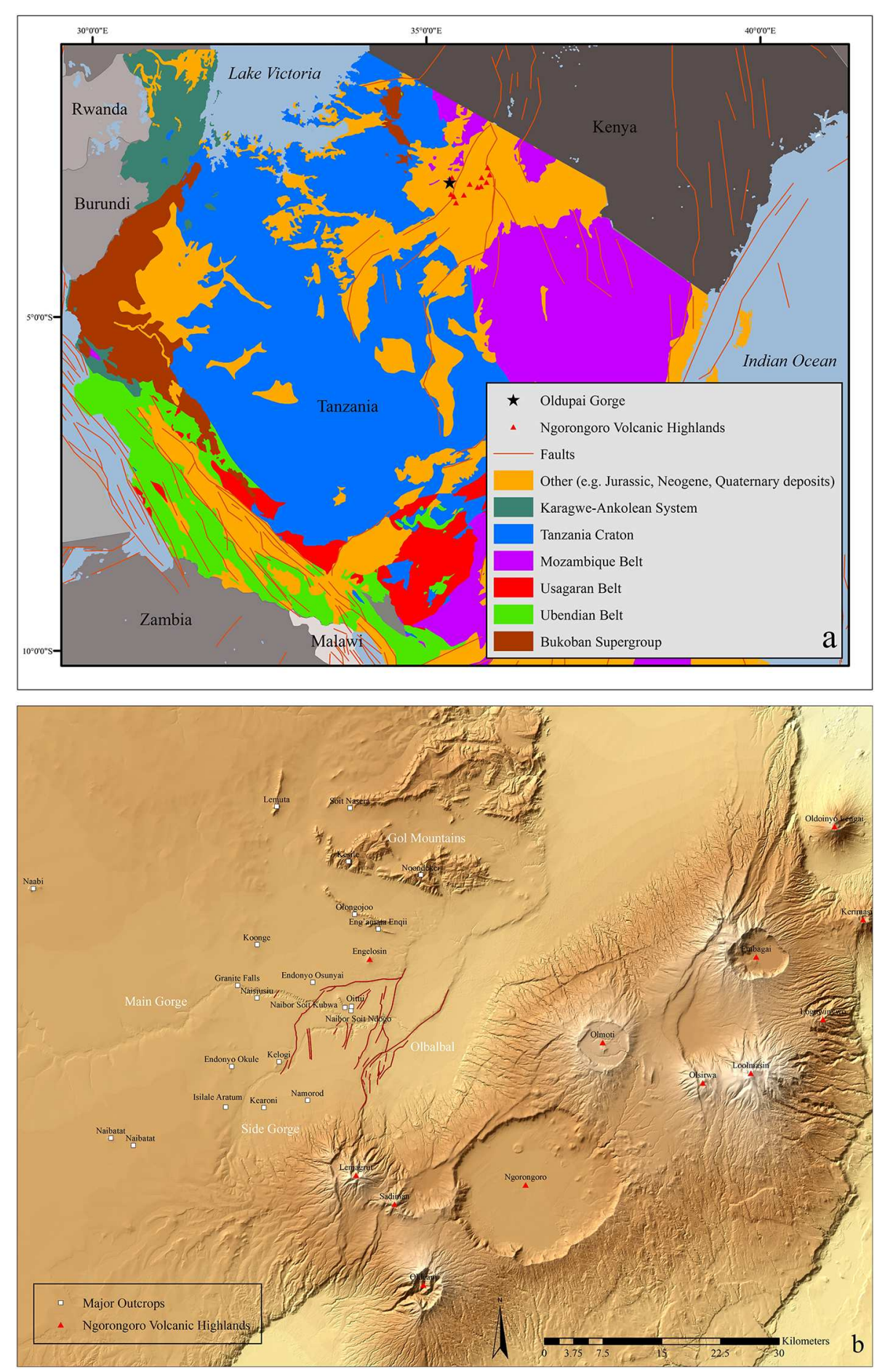

FIGURE 1 | (a) The East African Rift System superimposed over the Tanzania Craton, the Mozambique Belt, and other units. Geospatial data from Fritz et al. (2013) and Macgregor (2015). Refer to Kabete et al. (2012, Figure 5) for a detailed geological map of Tanzania. Refer to Scoon (2018, Figure 2.2) for a simplified stratigraphic column of East Africa. (b) Major geological outcrops in the greater Oldupai Gorge region. Faults after Hay (1976).

\section{Lithic Raw Materials}

Lithic industries including Earlier Stone Age (ESA), Middle Stone Age, and Later Stone Age assemblages are preserved in Oldupai's sedimentary record spanning from the Early Pleistocene to the Holocene (Leakey, 1971; Leakey et al., 1972; Mabulla, 1990; Leakey and Roe, 1994; Eren et al., 2014). While 
technological changes and the preferential use of certain rock types are evident (Leakey, 1971; Hay, 1976; Kyara, 1999), local raw material sources remained largely unchanged apart from two key exceptions: (1) chert formed during saline alkaline lake conditions and was subsequently exposed at lowstands (Hay, 1968, 1976; O’Neil and Hay, 1973; Stiles et al., 1974); and (2) conglomerates became available in the paleobasin through changes in regional drainage patterns that transported gravelsized clasts of igneous origin from the NVH (Hay, 1976). With such a diverse array of exploitable rock types conducive for toolmaking (Hay, 1976; Jones, 1994), hominins are believed to have applied some stone selection criteria. Proximity to raw material sources in the paleobasin also appears to have made long-distance transport of exotic rock types infrequent during Oldowan and Acheulean times (Leakey, 1971; Hay, 1976). Collectively, these factors make lithic raw material studies important to better understand the complexities of hominin resource procurement within a raw material-rich paleoecological setting such as Oldupai.

Our ability to understand hominin behavior from a technoecological perspective is hindered by two factors. First, it is welldocumented that raw material morphometry and mechanical properties, at and beyond Oldupai, affect the classification of artifact assemblages (Leakey, 1971; Kyara, 1999; Archer and Braun, 2010), and the behavioral interpretations gleaned from them such as the technical abilities of their makers (Jones, 1979, 1994). Second, while previous studies on Oldupai's lithic raw materials relied on macroscopic, petrographic, and geochemical techniques, they have not comprehensively characterized quartzitic outcrops (Leakey, 1971; Stiles et al., 1974; Hay, 1976; Stiles, 1991, 1998; Jones, 1994; Leakey and Roe, 1994; Kyara, 1999; Mollel, 2002; Tactikos, 2005; Blumenschine et al., 2008; Santonja et al., 2014; McHenry and de la Torre, 2018). Most recently, Egeland et al. (2019) studied local outcrops using a portable X-Ray Fluorescence spectroscope for chemical characterization and a Schmidt Hammer to determine fracture predictability. Based on statistical analyses, they assign Naibor Soit Kubwa as the likely source for three quartzite lithics from BK East (Bed II) (Egeland et al., 2019). Apart from this most recent study, the lack of characterization studies is unwarranted for several reasons. Most notably, research at Oldupai has been ongoing for over a century (Kent, 1978; Leakey, 1978; Hay, 1990), quartzite artifacts are ubiquitous (Leakey, 1971; Leakey and Roe, 1994), quartzite is of assumed importance based on experimental studies (Diez-Martín et al., 2011; de la Torre et al., 2013; Gurtov and Eren, 2014; Yustos et al., 2015; Byrne et al., 2016), and certain quartzitic outcrops have played a central role in discussions about hominin behavior in the Oldupai paleobasin (Leakey, 1971; Hay, 1976; Tactikos, 2005; Blumenschine et al., 2008). We previously developed a multi-scalar approach to characterize quartzites from different outcrops near Oldupai (Soto et al., 2020a), which integrates macroscopic properties, petrographic features, and chemical compositional data. In this study, we seek to provide detailed petrographic descriptions of lithologies in the Oldupai region and establish the prospects of sourcing stone tools based on petrographic data.

\section{MATERIALS AND METHODS}

\section{Field Sampling}

As part of the Stone Tools, Diet, and Sociality project, we sampled outcrops whose locations were determined from previous studies (Leakey, 1965, 1971; Hay, 1973, 1976; O’Neil and Hay, 1973; Stiles et al., 1974; Jones, 1979, 1981, 1994; Stiles, 1991, 1998; Manega, 1993; Kimura, 1997; Kyara, 1999; Hay and Kyser, 2001; Mollel, 2002, 2007; Plummer, 2004; Tactikos, 2005; Blumenschine et al., 2008, 2012; McHenry et al., 2008; Mollel et al., 2008; Berry, 2012; Mollel and Swisher, 2012; Zaitsev et al., 2012; Santonja et al., 2014) and knowledge gleaned from the local Maasai community. Samples were split using a geological hammer, photographed, and GPS coordinates were recorded using a Garmin eTrex 10. Structural and lithostratigraphic characteristics were noted for each outcrop. The samples studied herein covered the macroscopic varieties from most of the major outcrops in the Oldupai region (Table 1; Supplementary Table 1; see Soto et al., 2020a), including Endonyo Osunyai $(n=3)$ (Supplementary Figure 1), Engelosin $(n=4)$ (Supplementary Figure 2$)$, the Gol Mountains $(n=10)$ (Supplementary Figure 3), Granite Falls $(n=4) \quad$ (Supplementary Figure 4), Kelogi $(n=4)$ (Supplementary Figure 5), Naibor Soit Kubwa $(n=16)$ (Supplementary Figure 6), Naibor Soit Ndogo $(n=5)$ (Supplementary Figure 6), Naisiusiu $(n=8)$ (Supplementary Figure 7), Oittii $(n=4)$ (Supplementary Figure 6), and Olbalbal $(n=4)$ (Supplementary Figure 8).

\section{Macroscopic Description}

We conducted a macroscopic description of our samples as part of our multi-scalar characterization of raw materials (Soto et al., 2020a). Recorded criteria included morphology, Munsell color, grain size, texture, gloss, transparency, mineral composition, impurities, post-depositional alterations, and foliation. From our sample population, 38 quartzites were classified into 10 of 13 Raw Material Groups established for the Oldupai region (Tables 1, 4; Supplementary Table 2) (Soto et al., 2020a).

\section{Thin Sectioning and Petrographic Analysis}

Ten thin sections analyzed for this study were prepared at the Geoscience Research Laboratory (University of Calgary). The remaining samples were thin sectioned at the Tropical Archaeology Lab (University of Calgary) where these were cut flat (Trim Saw, TS10, Lortone Inc.; IsoMet 4000 Linear Precision Saw), slide-mounted on frosted slides $(27 \times 46 \mathrm{~mm})$ (Cast N' Vac 1000 Castable Vacuum System), ground to $30-35 \mu \mathrm{m}$ (PetroThin Thin Sectioning System), and polished (Metaserv 2000 Grinder Polisher).

A total of 74 thin sections were analyzed using a Leitz HM-POL petrographic microscope $(2.5,4,10,40 \times)$ (Table 1). Observation under plane-polarized and cross-polarized light allowed for mineral identification and rock type classification (Streckeisen, 1976; Le Bas and Streckeisen, 1991; Gill, 2010; Bucher and Grapes, 2011). Each rock's modal abundances were visually estimated by comparison with charts (Terry and 
TABLE 1 | Sample position, outcrop/source, ID, rock type, raw material group, number of thin sections per sample, and samples analyzed by SEM-EDS/EPMA.

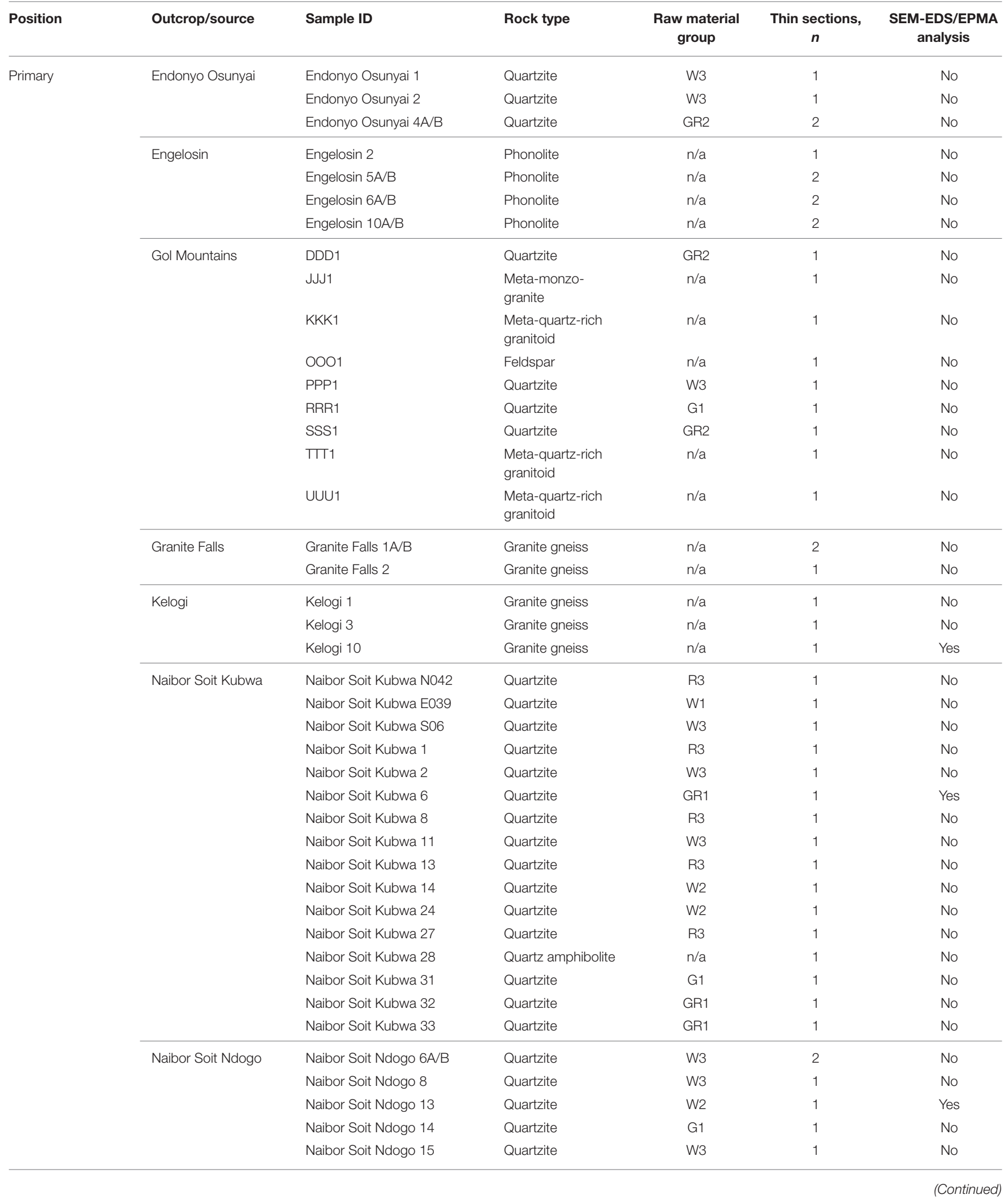


TABLE 1 | Continued

\begin{tabular}{|c|c|c|c|c|c|c|}
\hline Position & Outcrop/source & Sample ID & Rock type & $\begin{array}{c}\text { Raw material } \\
\text { group }\end{array}$ & $\begin{array}{c}\text { Thin sections, } \\
n\end{array}$ & $\begin{array}{c}\text { SEM-EDS/EPMA } \\
\text { analysis }\end{array}$ \\
\hline & Naisiusiu & Naisiusiu 3 & $\begin{array}{l}\text { Meta-syeno- } \\
\text { granite }\end{array}$ & $\mathrm{n} / \mathrm{a}$ & 1 & No \\
\hline & & Naisiusiu 4 & Quartzite & GR2 & 1 & Yes \\
\hline & & Naisiusiu 7 & Quartzite & GR1 & 1 & Yes \\
\hline & & Naisiusiu 8 & Mica schist & $\mathrm{n} / \mathrm{a}$ & 1 & No \\
\hline & & Naisiusiu 9 & Quartzite & W4 & 1 & No \\
\hline & & Naisiusiu 13 & Quartzite & GR1 & 1 & No \\
\hline & & Naisiusiu 14 & Quartzite & W3 & 1 & No \\
\hline & Oittii & Oittii 1A/B & Quartzite & GR2 & 2 & No \\
\hline & & Oittii 3 & Quartzite & W4 & 1 & No \\
\hline & & Oittii 4 & Quartzite & GR2 & 1 & No \\
\hline & & Oittii 5A/B & Quartzite & GR2 & 2 & No \\
\hline \multirow[t]{9}{*}{ Secondary } & Gol Mountains & III1 & $\begin{array}{l}\text { Hornblende } \\
\text { granofels }\end{array}$ & $\mathrm{n} / \mathrm{a}$ & 1 & Yes \\
\hline & Granite Falls & Granite Falls 3A/B & Nephelinite & $\mathrm{n} / \mathrm{a}$ & 2 & No \\
\hline & & Granite Falls 4A/B & Quartzite & W3 & 2 & No \\
\hline & Kelogi & Kelogi 9 & Quartzite & GR3 & 1 & Yes \\
\hline & Naisiusiu & Naisiusiu 12 & Nephelinite & $\mathrm{n} / \mathrm{a}$ & 1 & Yes \\
\hline & Olbalbal & $\mathrm{A} 1 \mathrm{~A} / \mathrm{B}$ & Nephelinite & $\mathrm{n} / \mathrm{a}$ & 2 & Yes \\
\hline & & $\mathrm{A} 2$ & Basalt & $\mathrm{n} / \mathrm{a}$ & 1 & No \\
\hline & & A5A/B & Basalt & $\mathrm{n} / \mathrm{a}$ & 2 & No \\
\hline & & A6 & Trachyandesite/basalt & $\mathrm{n} / \mathrm{a}$ & 1 & Yes \\
\hline
\end{tabular}

Chilingar, 1955). Textural characteristics such as crystal habit, morphology, replacement textures, intergrowths, and foliation were noted depending on rock type, and qualitative grain sizes were recorded (Supplementary Material Petrographic Descriptions; Supplementary Table 3). Photomicrographs were taken using a Nikon ECLIPSE 50i POL microscope (2, 4, $10,40 \times$ ) equipped with a Moticam 2500 (Motic Images Plus 2.0).

\section{SEM-EDS and EPMA}

Ten thin sections (Table 1) were analyzed at the Instrumentation Facility for Analytical Electron Microscopy (University of Calgary) using a FEI Quanta 250 FEG system equipped with a Bruker Quantax EDS for semi-quantitative analysis and backscatter electron (BSE) imaging. Observations and analyses were performed under an acceleration voltage of $15 \mathrm{kV}$, a pressure of $50 \mathrm{~Pa}$, and a measuring time of $20 \mathrm{~s}$. Spectra obtained from targeted minerals were identified by comparison with those from common rock forming minerals (Severin, 2004).

The 10 thin sections analyzed by SEM-EDS were also studied by EPMA (Table 1) at the University of Calgary Laboratory for Electron Microprobe Analysis, which enabled more accurate characterization of small grains. The laboratory houses a JEOL JXA-8200 electron microprobe with BSE imaging capabilities and a Bruker EDS system for semi-quantitative analysis. Samples were first carbon-coated, and observations and analyses were performed under an acceleration voltage of $15 \mathrm{kV}$, an emission current of $12 \mu \mathrm{A}$, and a measuring time of $20 \mathrm{~s}$.

\section{RESULTS}

The following sections, organized alphabetically by outcrop name, provide the geologic context for each outcrop and petrographic descriptions of samples.

\section{Endonyo Osunyai Geology}

Endonyo Osunyai consists of sporadically exposed quartzites and gneisses along a $\sim 100 \mathrm{~m}$ long stretch northwest of Naibor Soit Kubwa (Figure 1b). Quartzite is foliated and the foliation planes display a dominantly southerly dip with some exceptions (Figure 2A; Supplementary Figure 9). Gneissic lithologies are exposed along the northwestern part of the exposures where they show meso-scale deformation fabrics including folds (Figure 2B). 
A

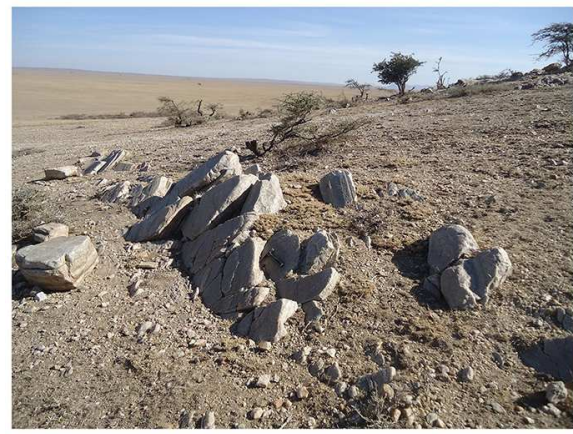

C

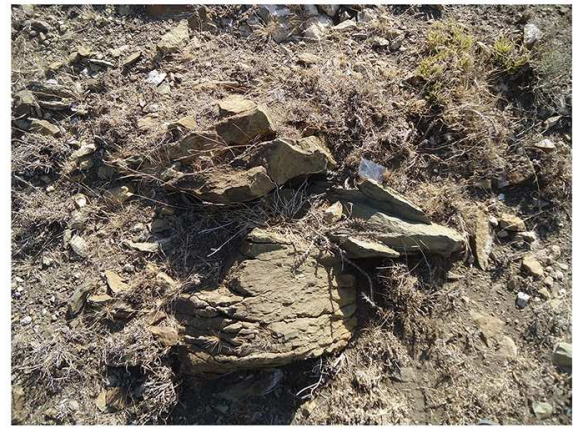

E

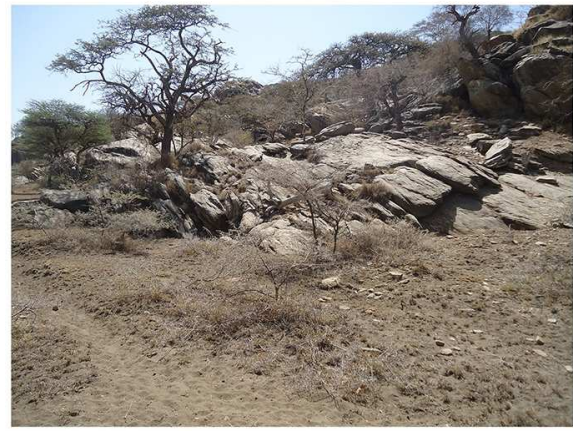

B

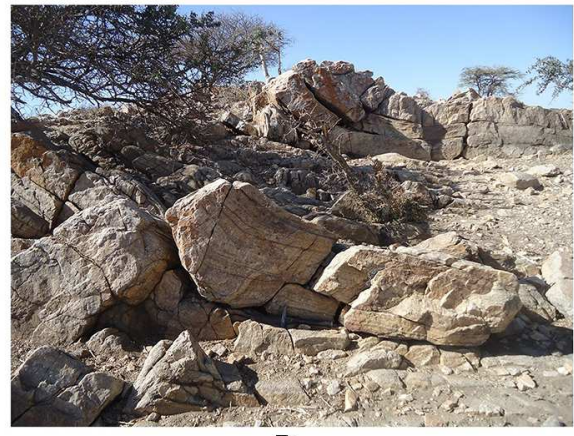

D
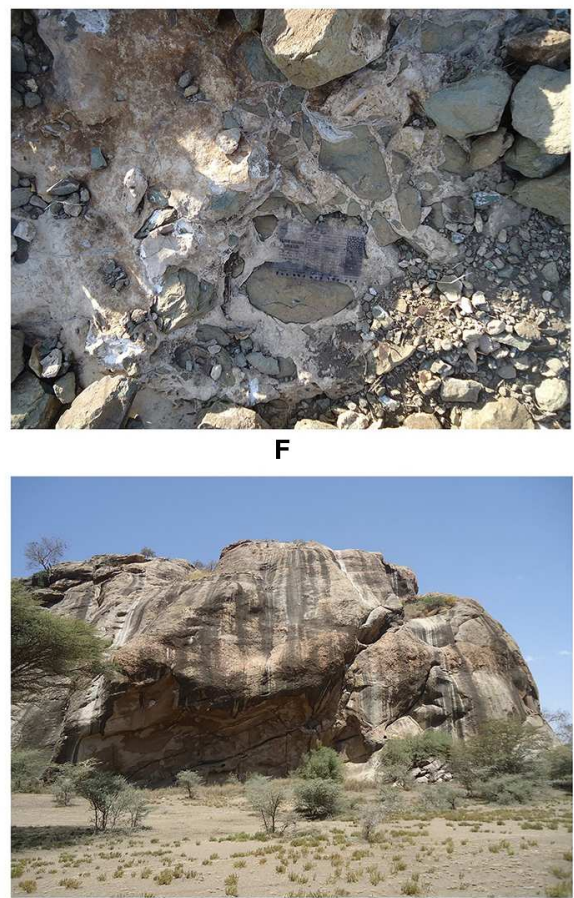

FIGURE 2 | Endonyo Osunyai: (A) Quartzites with foliation planes dipping south; (B) fractured gneiss outcrops showing one asymmetrical fold with harmonic folding; Engelosin: (C) weathered, oxidized, and fractured phonolite; (D) talus accumulations of phonolitic breccia cemented by calcrete; Gol Mountains: (E) west of Kesile, complexly deformed and exfoliated north-south trending granite gneiss outcrop with steeply-dipping foliation planes; (F) view south toward the rockshelter at Soit Nasera, a quartz-feldspathic monolith.

\section{Petrography}

Prior studies have identified gneiss and quartzite at Endonyo Osunyai, but no petrographic descriptions are available (Hay, 1976; Kyara, 1999). The quartzite is coarse-grained and accessory minerals include alkali feldspar, muscovite, hematite, and rutile (Figures 3A,B; Supplementary Figure 10) (Table 2) (Supplementary Section 1.1). Quartz crystals predominantly have sutured boundaries as a result of dynamic recrystallization (Stipp et al., 2002). Muscovite crystals have a platy habit, are either interstitial to or occur as inclusions in quartz, and generally show preferred alignment. Muscovite is responsible for weak foliation in samples containing alkali feldspar. No relict sedimentary textures are preserved.

\section{Engelosin Geology}

Engelosin is a $150 \mathrm{~m}$-high, weathered and oxidized phonolitic volcanic neck north of Oittii (Figures 1b, 2C; Supplementary Figure 11) (Mollel and Swisher, 2012). Eroded clasts and detritus from this outcrop are believed to have drained into the Oldupai paleobasin in combination with input from other volcanic centers of the NVH (Hay, 1976; Dawson, 2008; Mollel and Swisher, 2012). Volcaniclastic phonolitic breccia, 
TABLE 2 | Visually estimated modal percentages per sample.

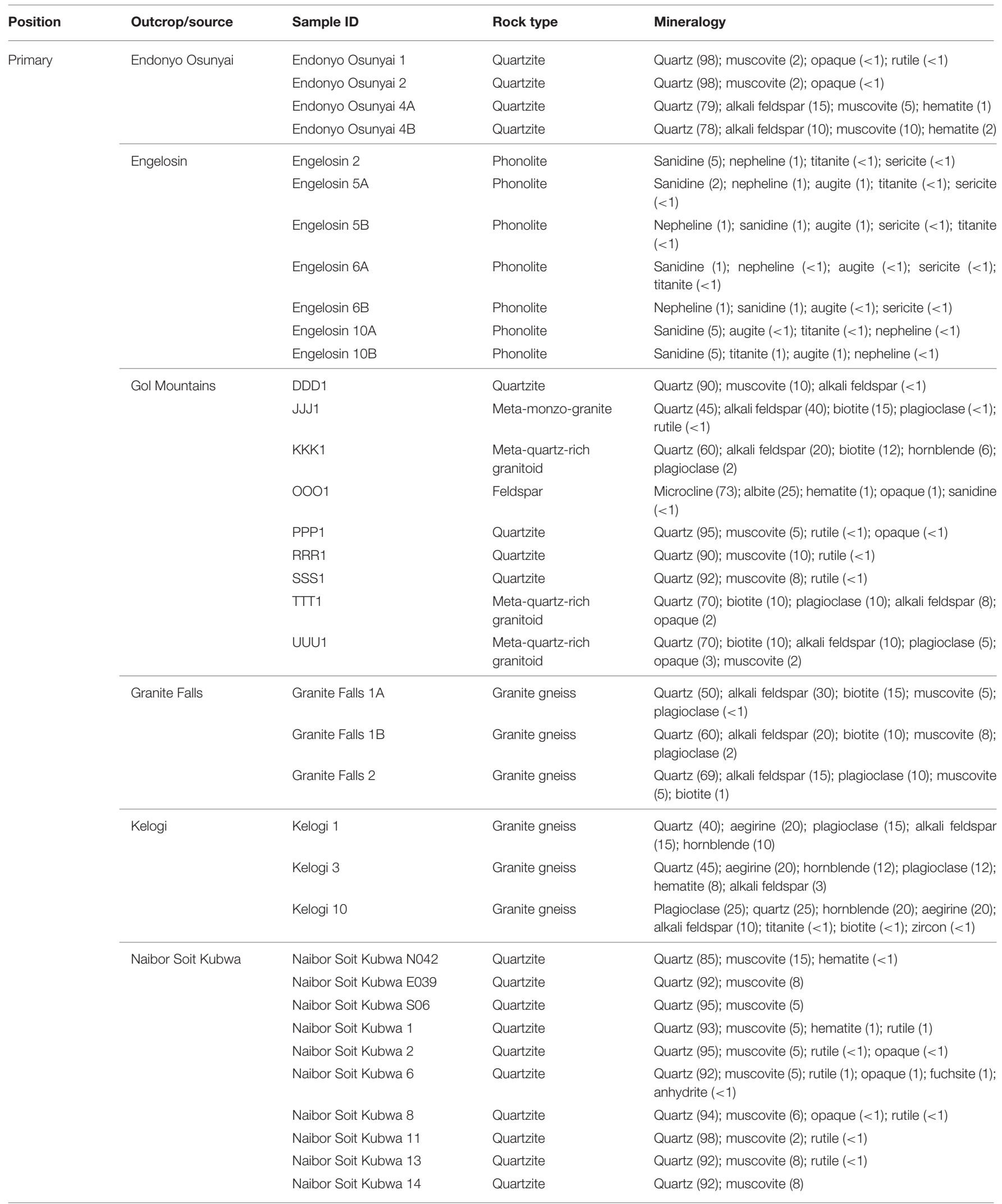


TABLE 2 | Continued

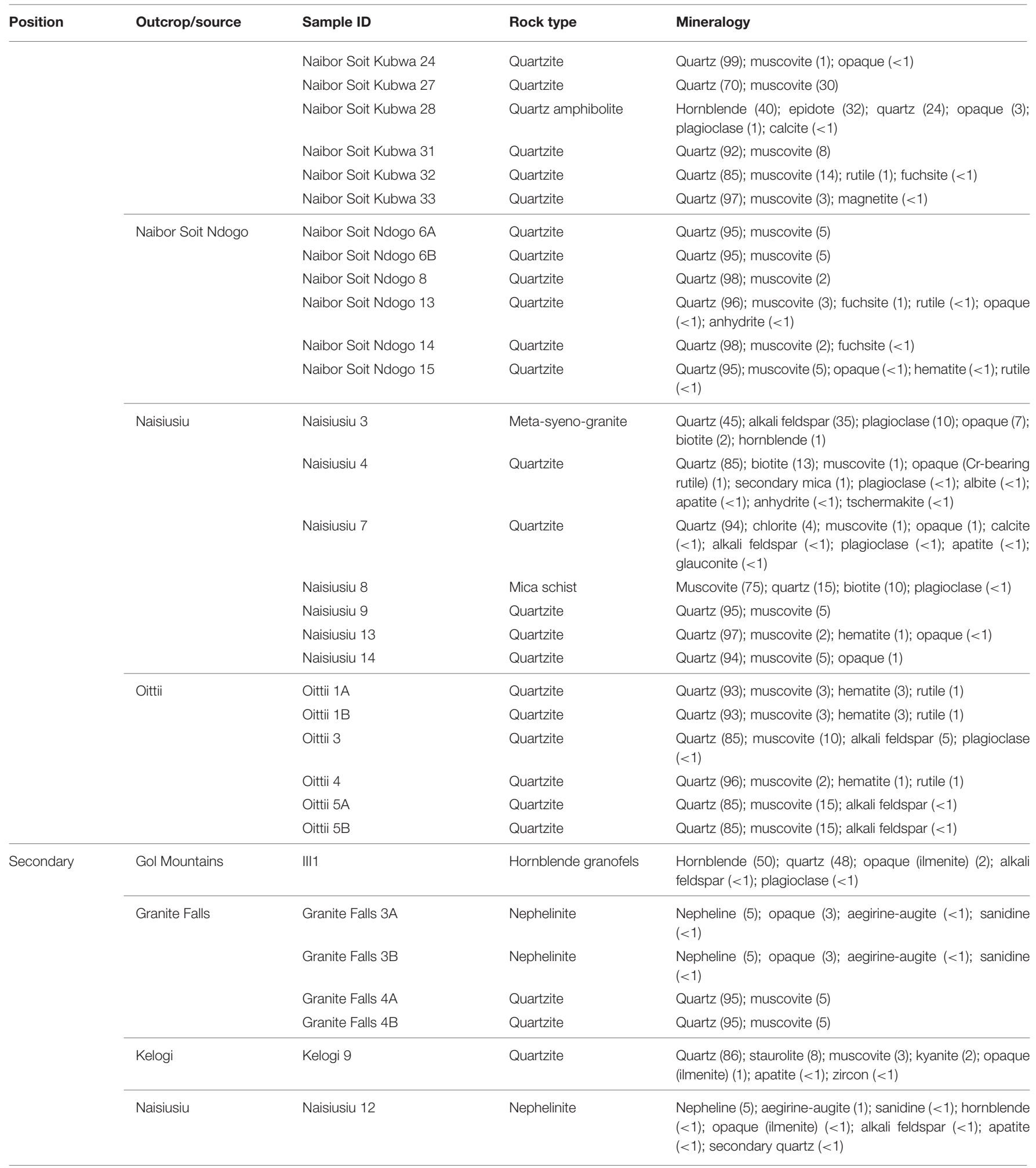


TABLE 2 | Continued

\begin{tabular}{|c|c|c|c|c|}
\hline Position & Outcrop/source & Sample ID & Rock type & Mineralogy \\
\hline & Olbalbal & A1A & Nephelinite & $\begin{array}{l}\text { Nepheline (65); aegirine-augite }(10) \text {; hornblende }(1) \text {; titanite } \\
(<1) \text {; titanoaugite }(<1) \text {; wollastonite }(<1) \text {; apatite }(<1) \text {; calcic } \\
\text { plagioclase }(<1) \text {; Cl-bearing silicates }(<1)\end{array}$ \\
\hline & & A1B & Nephelinite & $\begin{array}{l}\text { Nepheline (65); aegirine-augite }(10) \text {; hornblende }(1) \text {; titanite } \\
(<1) \text {; titanoaugite }(<1) \text {; wollastonite }(<1) \text {; apatite }(<1) \text {; calcic } \\
\text { plagioclase }(<1) \text {; Cl-bearing silicates }(<1)\end{array}$ \\
\hline & & A2 & Basalt & Plagioclase (20); opaque (1); augite (1); olivine (1) \\
\hline & & $\mathrm{A} 5 \mathrm{~A}$ & Basalt & Plagioclase (1); augite $(<1)$ \\
\hline & & $\mathrm{A} 5 \mathrm{~B}$ & Basalt & Plagioclase (1); augite $(<1)$ \\
\hline & & A6 & Trachyandesite/basalt & $\begin{array}{l}\text { Plagioclase }(1) \text {; kaersutite }(1) \text {; augite }(<1) \text {; alkali feldspar } \\
(<1) \text {; pyroxene }(<1) \text {; ilmenite }(<1) \text {; magnetite }(<1)\end{array}$ \\
\hline
\end{tabular}

Modes for igneous rocks are for phenocrysts. Modes for Kelogi 1 and 3 are based on point counts instead of visual estimates.

formed by calcrete cementation of talus fragments, blanket the unweathered parts of the volcanic neck (Figure 2D).

\section{Petrography}

Engelosin phonolite is green to gray, fine- to mediumgrained, and exhibits a variety of porphyritic and vesicular textures. Previous studies show alkali feldspar (anorthoclase and sanidine), augite, nepheline, aegirine, analcime, titanite, and apatite as constituent minerals (Hay, 1976; Kyara, 1999; Mollel and Swisher, 2012). We identified several phenocrysts including sanidine, nepheline, augite, and titanite together with minor amounts of sericite as an alteration product of feldspars (Figures 3C,D; Supplementary Figure 12) (Table 2) (Supplementary Section 1.2). Oxide phases are readily visible under thin section. Based on textural and mineralogical differences among four samples, there is one flow-aligned variety and a second with a felty texture (Table 3 ).

\section{Gol Mountains}

\section{Geology}

The Gol Mountains refers to primarily metamorphic inselbergs that transition northwards into a mountain range. These inselbergs begin to outcrop $\sim 4 \mathrm{~km}$ north of Engelosin and belong to the Mozambique Belt (Figures 1a,b). These outcrops represent a highly deformed complex that is typical of mobile belts (Figure 2E) (Scoon, 2018). The lithologies include limestones, schists, gneisses, quartzites, and migmatites (Cahen and Snelling, 1966; Cahen et al., 1984), which are occasionally oxidized and capped by calcretes. During the wet season, many inselbergs are drained by streams capable of transporting clasts several kilometers away (Supplementary Figure 13A). The local roads are sometimes bordered by lustrous phyllite which originates from a northern source according to local Maasai knowledge.

One of the most iconic inselbergs of the Gol Mountains is Soit Nasera (Figure 1b) (Scoon, 2018), a 350 m-high quartzfeldspathic monolith that is complexly deformed, faulted, exfoliated, varnished, and contains quartz veins and feldspar (Figure 2F). West and south of Soit Nasera are a variety of other inselbergs and low-lying outcrops composed of meta-granites and quartzites (Figure 1b; Supplementary Figures 13C,E,F). A total of nine samples from the Gol Mountains were analyzed in this study (Supplementary Figure 3) (Table 1; Supplementary Table 1).

\section{Petrography}

Previous studies reported quartzite at Olongojoo and near Soit Nasera but no detailed descriptions are available (Hay, 1976; Mehlman, 1977; Blumenschine et al., 2008; Reti, 2013). Accessory minerals present in coarse- and medium-grained quartzites include muscovite, alkali feldspar, and rutile (Table 2) (Supplementary Section 1.3). Quartz crystals exhibit sutured boundaries. Muscovite occurs as variably-sized platy crystals that are either interstitial to or included in quartz, and have either a random distribution or exhibit parallel lineation (Figures 3E,F). Muscovite crystals are responsible for weak foliation in one sample. Two samples show rutile concentrations or heavy mineral accumulations, likely a function of the original sedimentary protolith. Alkali feldspar and rutile are rare, but the overall mineralogy is consistent with a sandstone protolith although no relict sedimentary textures are preserved.

Meta-granites contain quartz, alkali feldspar, biotite, hornblende, plagioclase, rutile, and muscovite (Table 2) (Supplementary Section 1.3). All samples show hypidiomorphic textures. Quartz crystals show weak undulatory extinction and one sample contains granophyric intergrowths with alkali feldspar. Biotite, hornblende, and opaque crystals are responsible for the spotted and weakly foliated textures.

One sample of fine-grained leucocratic feldspar from Soit Nasera contains microcline, albite, hematite, opaque crystals, and sanidine (Table 2) (Supplementary Section 1.3). Similar rock types have been reported near Granite Falls but no petrographic descriptions are available (Hay, 1971, 1976).

One sample of fine-grained homeoblastic granofels contains hornblende, quartz, ilmenite, alkali feldspar, and plagioclase (Table 2) (Supplementary Section 1.3). Quartz crystals are generally euhedral with a granoblastic texture, and minor amounts are slightly deformed. SEM-EDS and EPMA analysis confirmed the presence of hornblende, quartz, and plagioclase, 


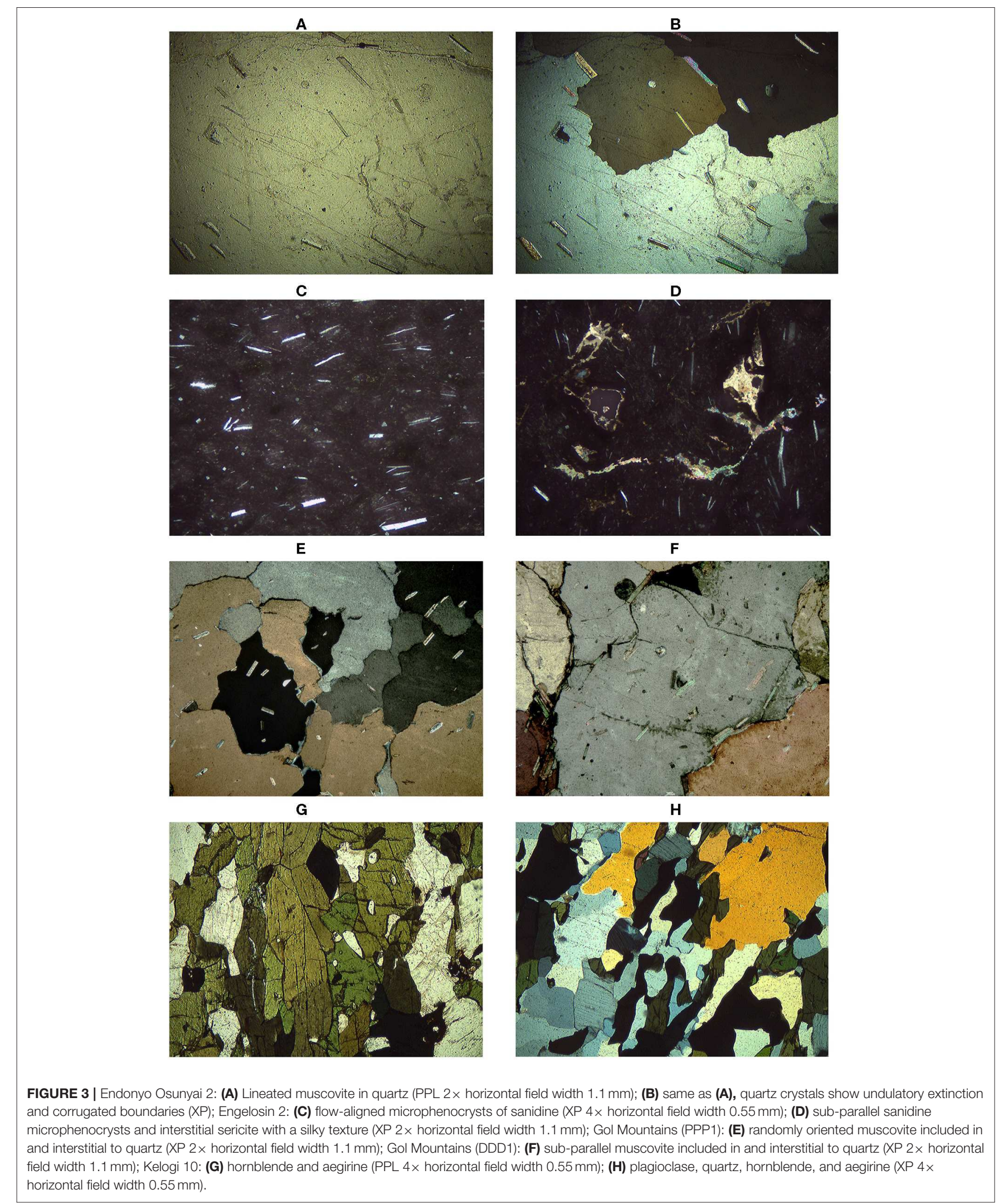


TABLE 3 | Textural data per magmatic sample.

\begin{tabular}{|c|c|c|c|c|c|}
\hline Sample ID & Rock type & Porphyry & $\begin{array}{l}\text { Porphyritic } \\
\text { texture }\end{array}$ & Groundmass & $\begin{array}{l}\text { Groundmass } \\
\text { texture }\end{array}$ \\
\hline Engelosin 2 & Phonolite & Microporphyritic & Flow-aligned & Light-green & Trachytic \\
\hline Engelosin 5A & Phonolite & Microporphyritic & Felty & Light-green & Felty \\
\hline Engelosin 5B & Phonolite & Microporphyritic & Felty & Light-green & Felty \\
\hline Engelosin $6 \mathrm{~A}$ & Phonolite & Microporphyritic & Flow-aligned & Light-green & Trachytic \\
\hline Engelosin 6B & Phonolite & Microporphyritic & Flow-aligned & Light-green & Trachytic \\
\hline Engelosin 10A & Phonolite & Microporphyritic & Flow-aligned & Light-gray & Trachytic \\
\hline Engelosin 10B & Phonolite & Microporphyritic & Flow-aligned & Light-gray & Trachytic \\
\hline Granite Falls 3A & Nephelinite & Microporphyritic & Weakly aligned & Light-brown & Flow-aligned \\
\hline Granite Falls 3B & Nephelinite & Microporphyritic & Weakly aligned & Light-brown & Flow-aligned \\
\hline Naisiusiu 12 & Nephelinite & Microporphyritic & Flow-aligned & Brown-gray & Flow-aligned \\
\hline $\mathrm{A} 1 \mathrm{~A}$ & Nephelinite & Porphyritic & Weakly aligned & Dark-brown & Weakly aligned \\
\hline A1B & Nephelinite & Porphyritic & Weakly aligned & Dark-brown & Weakly aligned \\
\hline $\mathrm{A} 2$ & Basalt & Porphyritic & Flow-aligned & Light-gray & Trachytic \\
\hline A5A & Basalt & Porphyritic & Flow-aligned & Light-gray & Trachytic \\
\hline A5B & Basalt & Porphyritic & Flow-aligned & Light-gray & Trachytic \\
\hline A6 & Trachyandesite/basalt & Microporphyritic & Felty & Light-gray & Felty \\
\hline
\end{tabular}

and allowed the identification of opaque crystals seen under thin section as ilmenite (Supplementary Figures 14, 15). This sample was collected in a seasonal stream channel draining Olongojoo (Figure 1b; Supplementary Figure 13A) which suggests that granofelsic rocks are present at this inselberg in addition to quartzite (Hay, 1976; Blumenschine et al., 2008).

\section{Granite Falls \\ Geology}

Granite Falls comprise metamorphosed granitic lithologies that underlie the sedimentary units in the western Oldupai paleobasin (Hay, 1976). The outcrop is partly exfoliated, faulted, and varnished while the joints trend east-west (Figure 4A; Supplementary Figures 16A,B). The Oldupai River flows through Granite Falls during the wet season depositing igneous and metamorphic clasts (Supplementary Figures 16C,D).

\section{Petrography}

Hay (1976) reported quartz, microcline, plagioclase, biotite, and muscovite in gneiss rocks from this outcrop. Granite gneiss samples analyzed in this study contain quartz, alkali feldspar, biotite, muscovite, and plagioclase (Table 2) (Supplementary Section 1.4). Some thin sections have granoblastic textures while others are highly deformed. One sample contained deformed quartz with crack-seal structures filled by muscovite microveins. Muscovite predominantly occurs as platy crystals that are either interstitial to or included in other crystals. Biotite is the defining foliation mineral.

One sample of nephelinite recovered from the riverbed (Supplementary Figure 16C) is inequigranular and contains nepheline, aegirine-augite, and sanidine microphenocrysts which are included in a flow-aligned light-brown groundmass (Tables 2, 3) (Supplementary Section 1.4). This sample originates from Sadiman based on mineralogical similarities (Zaitsev et al., 2012).

One sample of quartzite discovered in the riverbed (Supplementary Figure 16D) is weakly foliated with a heteroblastic texture, and has a mineral assemblage of quartz and rare muscovite (Table 2) (Supplementary Section 1.4). Quartz crystals have sutured boundaries. Muscovite crystals are either interstitial to or inclusions in quartz, have a parallel lineation, and are occasionally lozenge-shaped with fragment trails. This sample's source is unknown and does not resemble quartzites from Naisiusiu.

\section{Kelogi \\ Geology}

Kelogi refers to a series of northeast-southwest trending granite gneiss inselbergs west of the Side Gorge (Figure 1b). The outcrops are distributed over $\sim 2 \mathrm{~km}$ and are complexly deformed, faulted, exfoliated, varnished, and contain quartz and mafic veins occasionally oriented perpendicular to weak foliation planes (Figures 4B,C; Supplementary Figure 17). Kelogi clasts and detritus contributed to sedimentary infill of the Oldupai paleobasin (Hay, 1976).

\section{Petrography}

Previous studies of granite gneiss have reported quartz, orthoclase, albite, aegirine, hornblende, biotite, and garnet (Hay, 1976; Kyara, 1999). Medium- to fine-grained granite gneiss samples analyzed in this study contain quartz, aegirine, plagioclase, hornblende, alkali feldspar, hematite, titanite, biotite, and zircon (Table 2) (Supplementary Section 1.5). Quartz crystals are anhedral and commonly show undulatory extinction. Hornblende and aegirine define foliation resulting in a gneissose texture (Figures 3G,H; Supplementary Figure 18). 
A
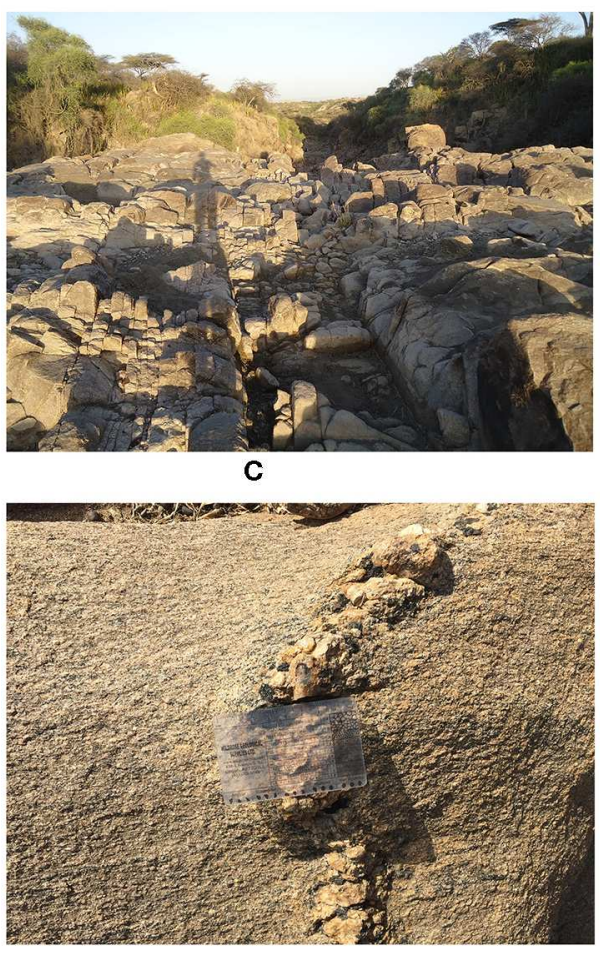

E

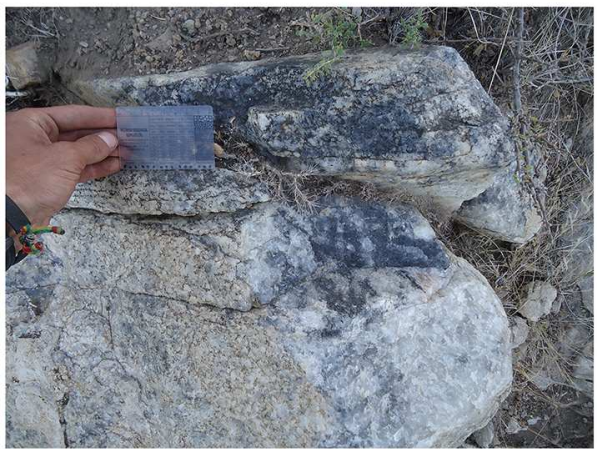

B

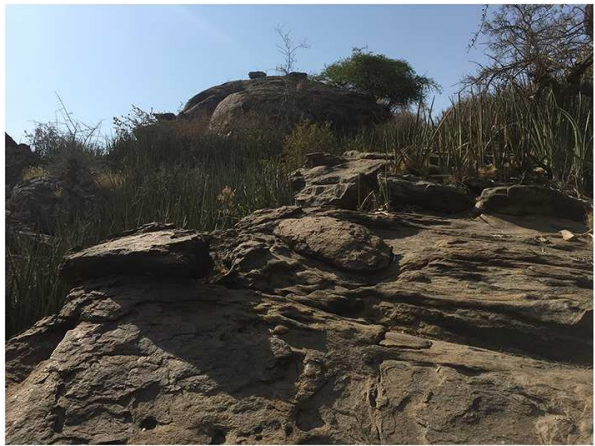

D

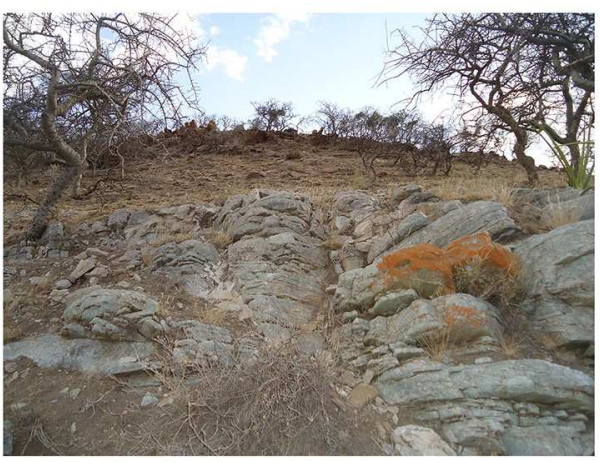

$\mathbf{F}$

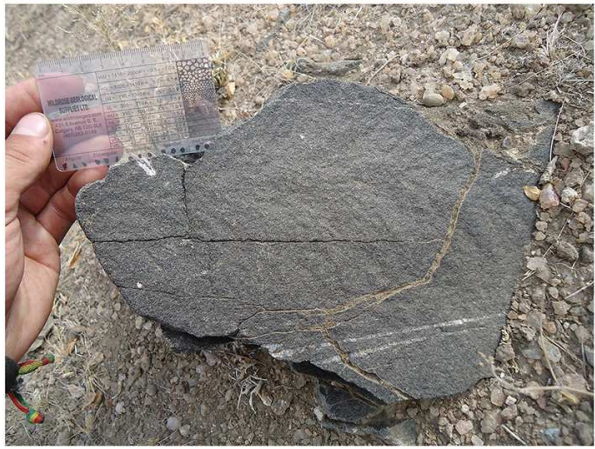

FIGURE 4 | Granite Falls: (A) View east showing jointed granite gneiss forming the riverbed of the seasonal Olduvai River; Kelogi: (B) complexly deformed, weathered, and varnished granite gneiss; (C) close-up of a quartz and mafic vein; Naibor Soit Kubwa: (D) quartzite with foliation planes dipping west overlain by gneiss outcrops; (E) magnetite-rich quartzite on the eastern side of the inselberg; (F) portion of the amphibolite dyke with sub-parallel quartz veins.

Zircons were identified under SEM-EDS and EPMA (Supplementary Figures 19, 20).

One quartzite sample in secondary position is fine-grained, and has a mineral assemblage of quartz, staurolite, muscovite, kyanite, ilmenite, zircon, and apatite (Figures 5A,B) (Table 2) (Supplementary Section 1.5). Quartz crystals are anhedral and show undulatory extinction. Muscovite and kyanite crystals are either interstitial to or occur as inclusions in quartz, and have a parallel lineation. SEM-EDS and EPMA analysis allowed the identification of zircon and apatite, and helped identify opaque crystals seen under thin section as ilmenite (Figures 6A,B; Supplementary Figures 21, 22). This sample originates from either Endonyo Okule or Naisiusiu based on mineralogical similarities (see section Quartzites) (Hay, 1976: Table 6).

\section{Naibor Soit Kubwa \\ Geology}

Naibor Soit Kubwa is a $\sim 1.8 \mathrm{~km}$-long, northwest-southeast trending quartzitic and gneissic inselberg west of Naibor Soit Ndogo (Figure 1b). Most of the foliation planes dip northwest, west, or southwest (Figures 4D,E; Supplementary Figure 23). The outcrop principally consists of coarse- to mediumgrained varieties of white, gray, orange, pink, red, and green 

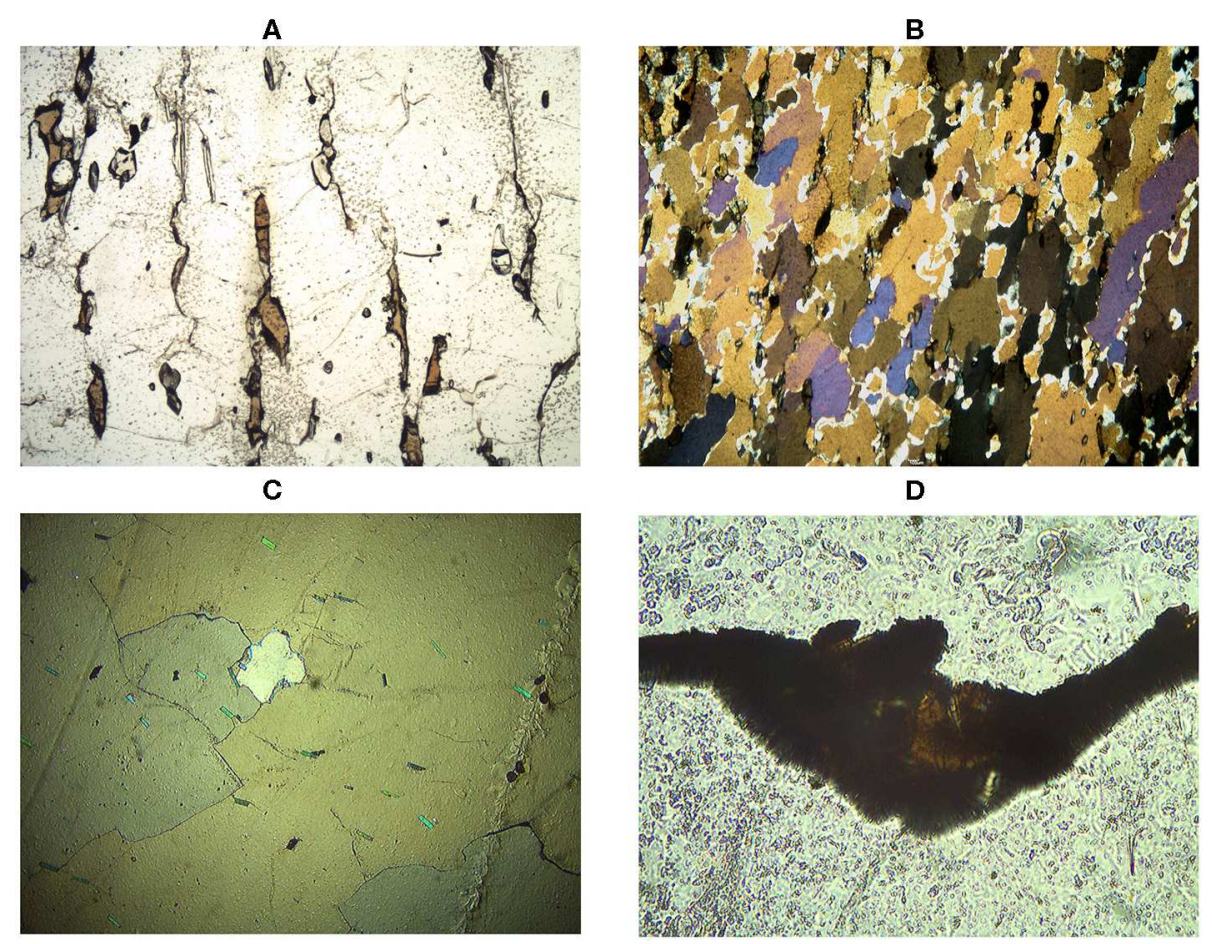

E
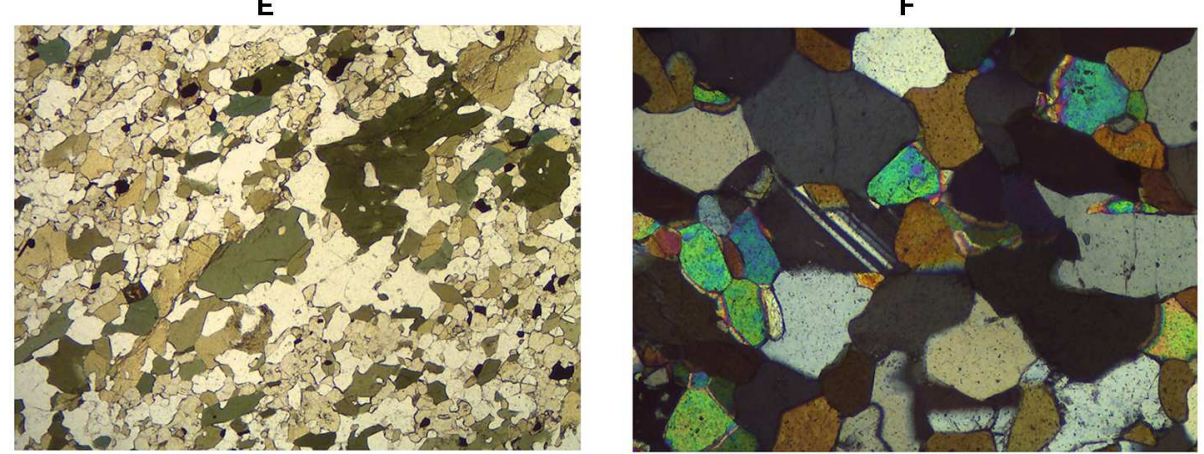

G

H
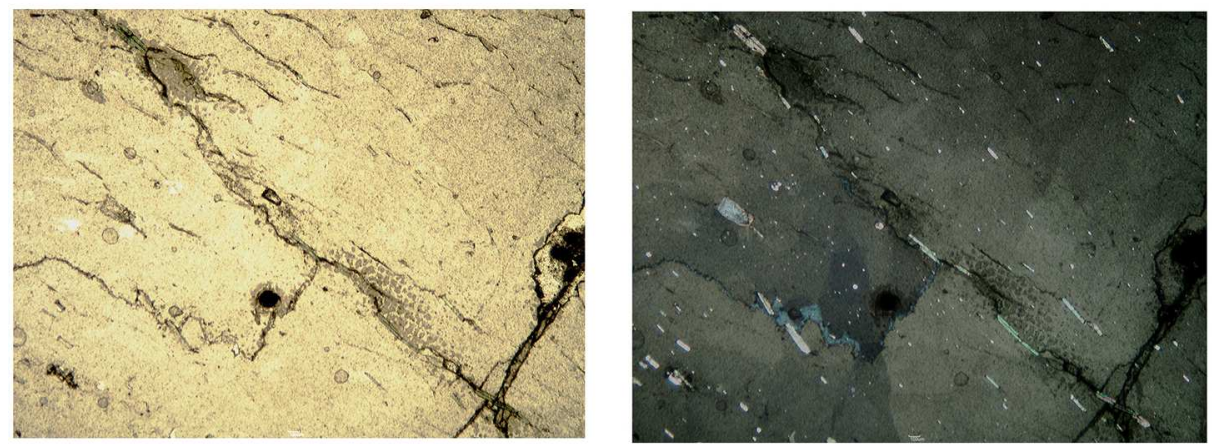

FIGURE 5 | Kelogi 9: (A) Quartz, staurolite, muscovite, and kyanite (PPL 4x horizontal field width $0.55 \mathrm{~mm}$ ); (B) similar to (A) note the fine-grained texture (XP 2x horizontal field width $1.1 \mathrm{~mm}$ ); Naibor Soit Kubwa 33: (C) sub-parallel muscovite crystals included in and interstitial to quartz (XP 2x horizontal field width 1.1 mm); (D) magnetite crystal with dark metallic luster and a dendritic habit (PPL 40x horizontal field width $0.055 \mathrm{~mm}$ ); Naibor Soit Kubwa 28: (E) foliation defined by hornblende (PPL 2x horizontal field width $1.1 \mathrm{~mm}$ ); (F) plagioclase crystal with characteristic polysynthetic twinning surrounded by quartz and epidote (XP 10x horizontal field width $0.22 \mathrm{~mm}$ ); Naibor Soit Ndogo 13 (thin section damaged during preparation): (G) pale green fuchsite crystals and colorless muscovite included in and interstitial to quartz (PPL 2x horizontal field width $1.1 \mathrm{~mm}$ ); (H) same as (G) note the platy habit of fuchsite and muscovite (XP). 
Favreau et al.

Raw Material Characterization at Oldupai

A

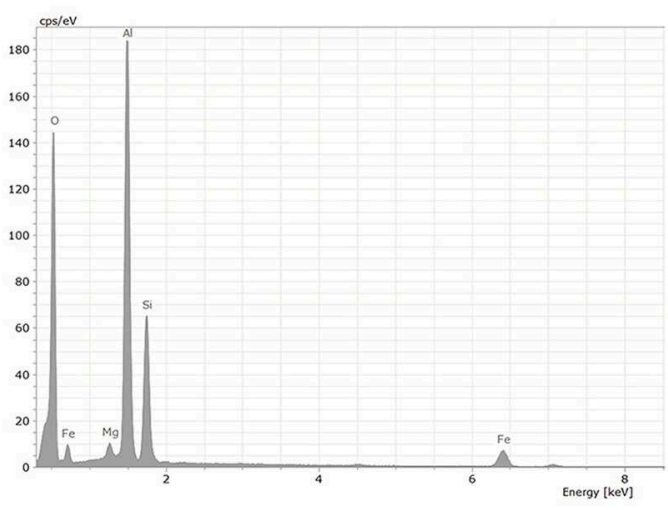

C

20

E

G

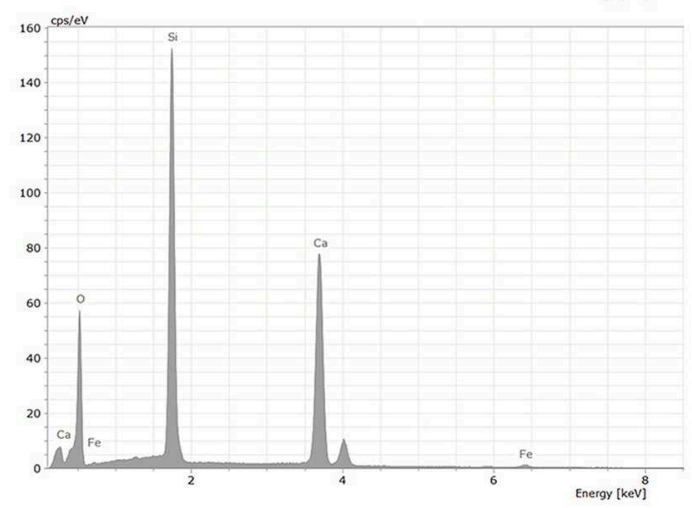

B

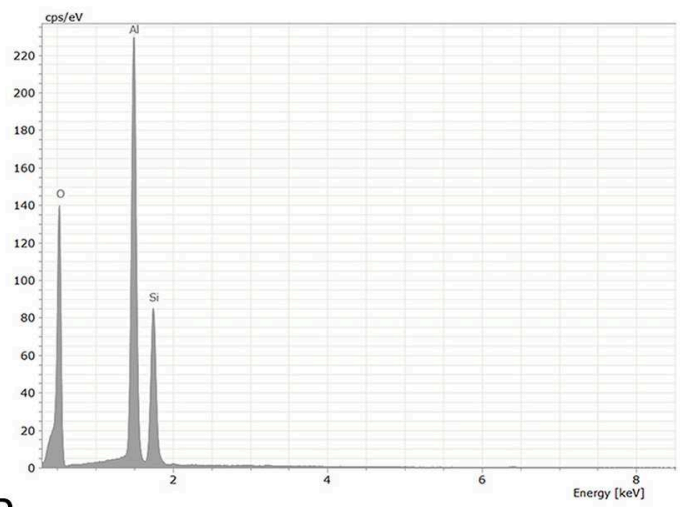

D

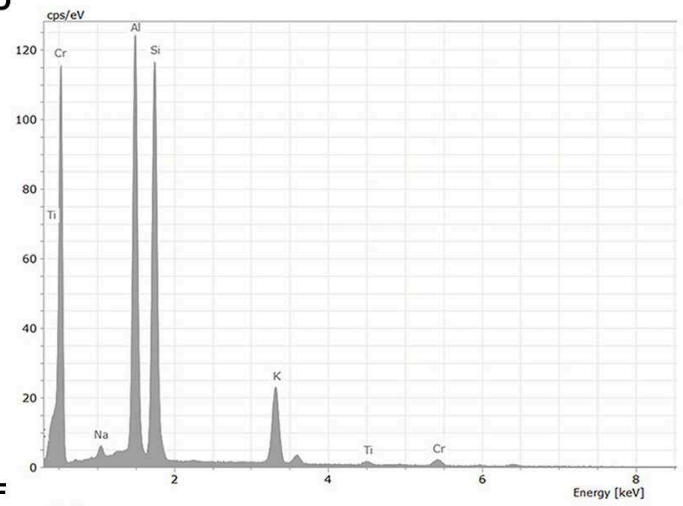

F

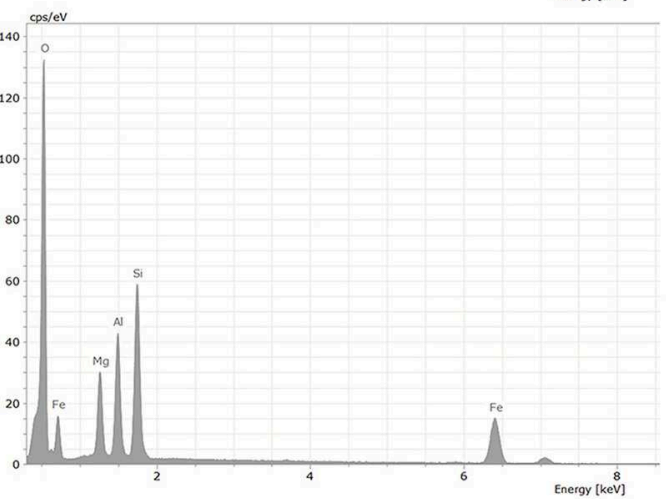

H

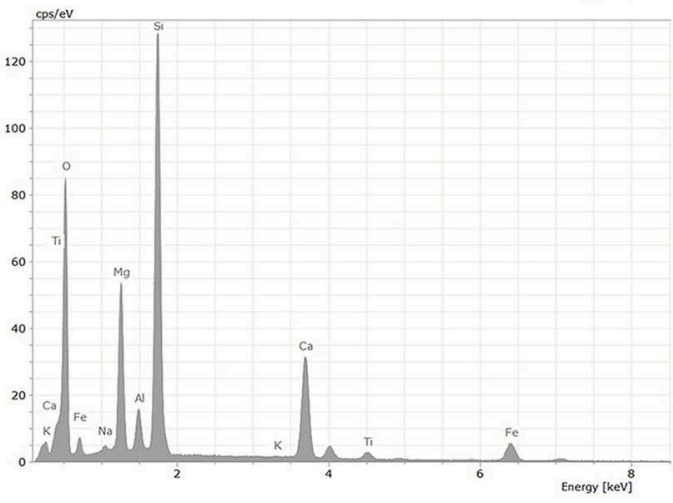

FIGURE 6 | X-ray spectra (EDS) of minerals obtained using EPMA: (A) Staurolite and (B) kyanite in Kelogi 9; (C) anhydrite in Naibor Soit Kubwa 6; (D) fuchsite in Naibor Soit Ndogo 13; (E) biotite in Naisiusiu 4; (F) glauconite in Naisiusiu 7; (G) wollastonite in A1A; (H) kaersutite in A6. Refer to Table 2 and

Supplementary Section 1 for additional sample information. Refer to Supplementary Figures 22, 27, 33, 37, 39, 46, 49 for unclipped spectra.

Frontiers in Earth Science | www.frontiersin.org

15

May 2020 | Volume 8 | Article 158 
quartzites that are occasionally oxidized and capped by calcretes (Supplementary Figure 23). The inselberg's clasts and detritus contributed to sedimentary infill of the Oldupai paleobasin (Hay, 1976). Protruding through the top of the inselberg in the northwestern sector is a prominent amphibolite dyke with subparallel quartz veins (Figure 4F; Supplementary Figures 23E,F). The northern and western sides of the outcrop bear sand deposits. The northern deposits are aeolian and originate from nearby barchan (mafic) sand dunes that travel westward according to prevailing winds (Hay, 1976). The western deposits are a combination of mafic sands and felsic erosional by-products from the outcrop.

\section{Petrography}

Previous studies have identified gneiss and coarse-grained quartzite with rare muscovite (Hay, 1976; Kyara, 1999; Tactikos, 2005; McHenry and de la Torre, 2018). Accessory minerals present in coarse- to fine-grained quartzites include muscovite and rutile, and rare hematite, fuchsite, magnetite, and anhydrite (Figures 5C,D, 6C; Supplementary Figures 24-27) (Table 2) (Supplementary Section 1.6). Quartz crystals typically display sutured boundaries. Muscovite crystals are either interstitial to or included in quartz, and predominantly show parallel to subparallel lineation. Muscovite crystals are responsible for foliated quartzites. Rare occurrences of fuchsite, a chromium-rich variety of muscovite, occur as small crystals that are either interstitial to or included in quartz. Hematite is commonly interstitial to quartz. The mineral assemblages of quartzite are consistent with a sandstone protolith and one sample preserved a relict sedimentary texture (Supplementary Section 1.6). Anhydrite crystals are present which may be of evaporitic origin.

Fine-grained gneissose (defined by hornblende) quartz amphibolite was sampled from a previously unrecorded metamafic dyke cross-cutting the quartzite-dominated inselberg (Figure 4F; Supplementary Figures 23E,F). The mineral assemblage of hornblende, epidote, quartz, opaque crystals, plagioclase, and calcite (Figures 5E,F; Supplementary Figure 28) (Table 2) (Supplementary Section 1.6) is typical of a basaltic protolith metamorphosed into amphibolite. Metamorphic processes may have impacted surrounding quartzrich lithologies which may explain the high proportion of quartz and the presence of foliation-parallel quartz veins (Figure 4F).

\section{Naibor Soit Ndogo \\ Geology}

Naibor Soit Ndogo is a $\sim 1 \mathrm{~km}$-long, northwest-southeast trending quartzitic inselberg east of Naibor Soit Kubwa (Figure 1b). The westernmost quartzites have foliation planes that steeply dip south and southwest while the easternmost foliation planes steeply dip southwest and west (Figure 7A; Supplementary Figure 29). The outcrop principally consists of coarse- to medium-grained varieties of white, orange, pink, and green quartzites that are occasionally oxidized (Figure 7B; Supplementary Figure 29). The easternmost outcrops bear evidence of heat-induced staining (Supplementary Figure 29D).

\section{Petrography}

Previous studies have identified coarse-grained quartzite with a mineral assemblage of quartz and rare muscovite (Leakey, 1965; Hay, 1976; Kyara, 1999; Santonja et al., 2014; BelloAlonso et al., 2020). Accessory minerals present in coarse-grained quartzites include muscovite, rare fuchsite, rutile, hematite, and anhydrite (Figures 5G,H, 6D; Supplementary Figures 30-33; Table 2; Supplementary Section 1.7). Quartz crystals typically display sutured boundaries. Muscovite occurs as platy crystals that are either interstitial to or included in quartz. Muscovite crystals generally have a parallel to sub-parallel lineation and are responsible for weak foliation in some samples. Muscovite crystals are occasionally lozenge-shaped with fragment trails, and form bookshelf-sliding microstructures. Rare occurrences of fuchsite occur as small crystals that are either included in quartz or interstitial (Figures 5G,H; Supplementary Figure 30). Rutile is a rare accessory mineral and hematite generally occurs interstitial to quartz. The mineral assemblages are suggestive of a sandstone protolith although no relict sedimentary textures are preserved.

\section{Naisiusiu}

\section{Geology}

Naisiusiu is a low-lying, east-west trending quartzitic, schistose, and meta-granitic outcrop $\sim 3 \mathrm{~km}$ southeast of Granite Falls (Figures 1b, 6C,D; Supplementary Figure 34). The quartzite and schists have foliation planes dipping south. The top and northern sides of the outcrop show greater exposure than the southern and eastern sides likely resulting from mining activities (Supplementary Figure 34A). The outcrop principally consists of medium-grained varieties of white, gray, red, and purple quartzites interlayered by mica schist (Figures 7C,D; Supplementary Figures 34E,F) along with meta-granitic bodies with uncertain structural relationships to the former.

\section{Petrography}

Previous studies on quartzite have identified quartz, microcline, muscovite, garnet, kyanite, and staurolite (Hay, 1976; Kyara, 1999; Tactikos, 2005; McHenry and de la Torre, 2018). Coarse- to fine-grained quartzites have diverse mineral assemblages, but are mostly dominated by quartz, biotite, muscovite, opaque crystals, hematite, and calcite (Table 2) (Supplementary Section 1.8). Quartz crystals show undulatory extinction. Muscovite crystals have a platy habit, are either interstitial to or inclusions in quartz, and have a parallel to random lineation (Figures 8A,B; Supplementary Figure 35). Some samples show variably-sized quartz grains, quartz overgrowths, and interstitial cement which suggest poorly-sorted sandstone protoliths. Biotite and chlorite are responsible for weak foliation in some samples. SEM-EDS and EPMA allowed the identification of biotite, potassium feldspar, plagioclase, albite, apatite, anhydrite, glauconite, secondary mica, tschermakite, and deeply-colored rutile (Figures 6E,F; Supplementary Figures 36-39).

Previous studies on granite gneiss have identified quartz, microcline, plagioclase, aegirine, hornblende, titanite, and biotite as mineral constituents (Hay, 1976; Kyara, 1999). Here, we identified quartz, alkali feldspar, plagioclase, biotite, and 


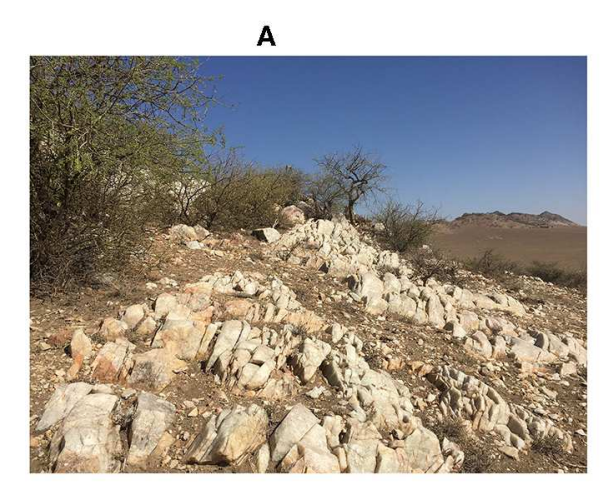

c

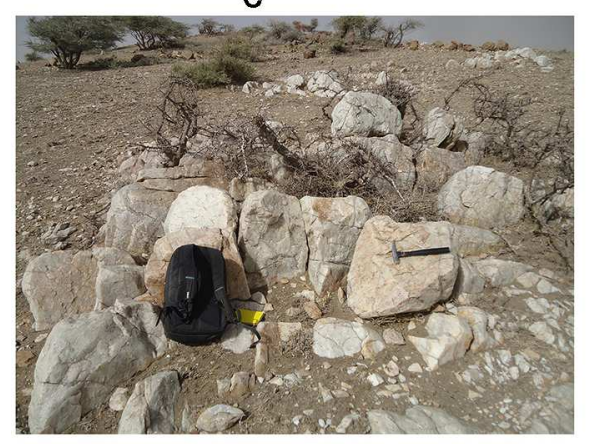

E

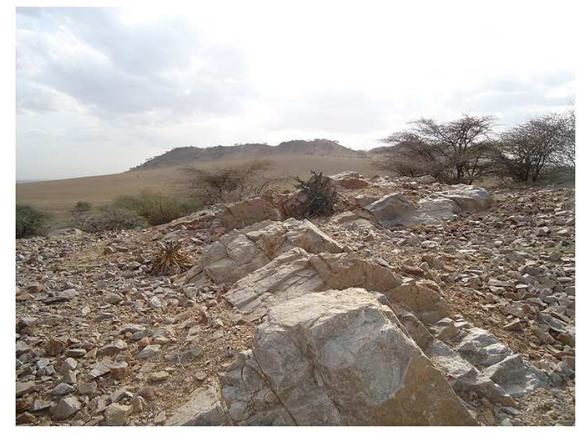

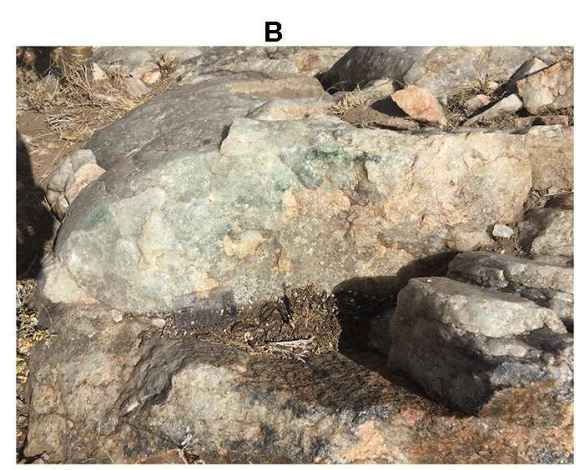

D

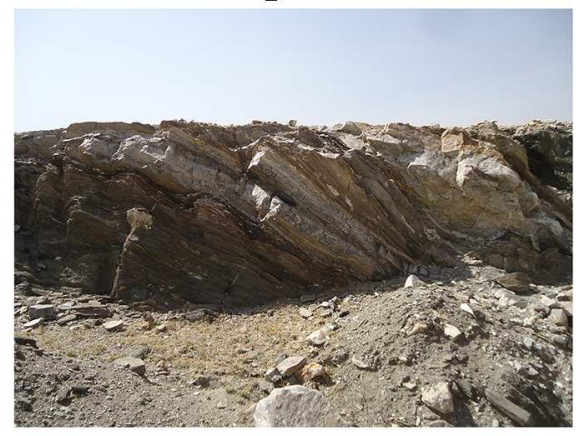

$\mathbf{F}$

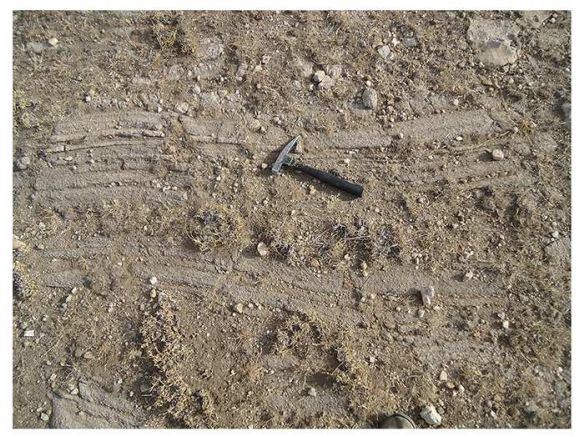

G

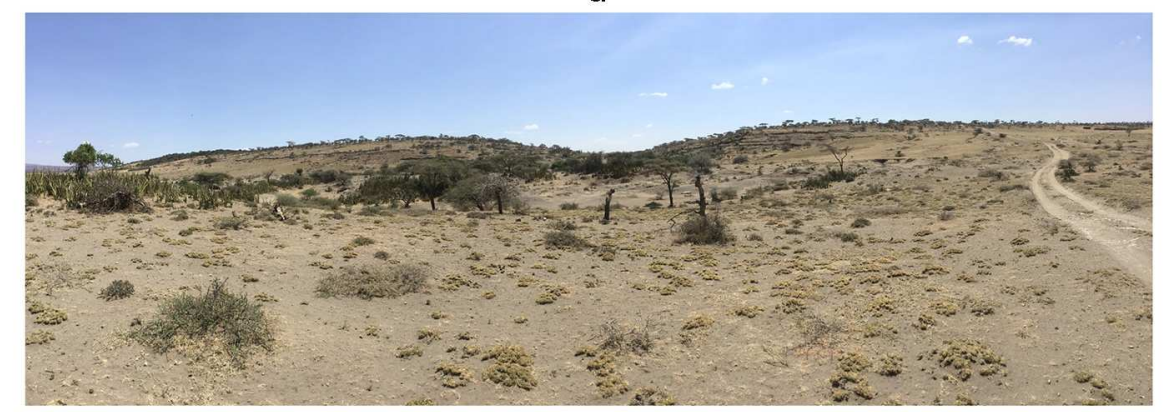

FIGURE 7 | Naibor Soit Ndogo: (A) View west toward Naibor Soit Kubwa showing quartzite foliation planes steeply dipping south; (B) fuchsite-bearing quartzite on the southern side of the inselberg; Naisiusiu: (C) quartzitic (foreground) and meta-granitic (background) lithologies on the northern side of the outcrop; (D) mica schist overlain by quartzite with foliation planes dipping southeast; Oittii: (E) view west toward Naibor Soit Kubwa showing quartzite foliation planes dipping north; (F) east-west trending steeply dipping mica schist with harmonic folding; Olbalbal: (G) panoramic view northwest toward Oldupai Gorge's First Fault.

hornblende in one sample of medium- to fine-grained metasyeno-granite with a hypidiomorphic texture (Table 2). Quartz crystals are anhedral and show undulatory extinction. Opaque crystals are responsible for this rock's spotted texture.
One sample of medium- to fine-grained mica schist contains muscovite, quartz, biotite, and plagioclase (Table 2). The texture is primarily lepidoblastic but partly decussate. Muscovite crystals are responsible for the foliated texture. 


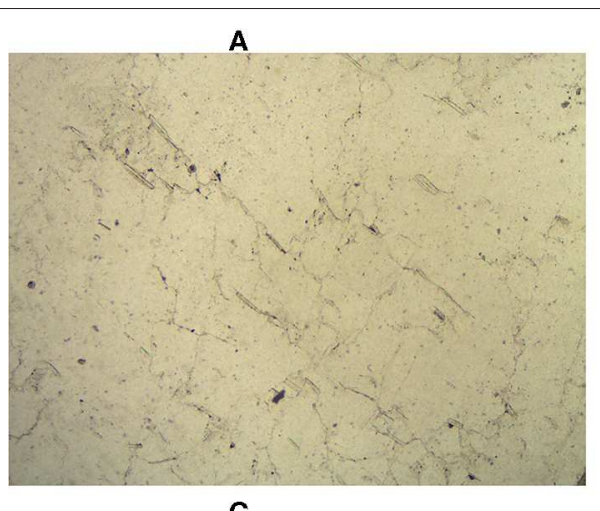

C

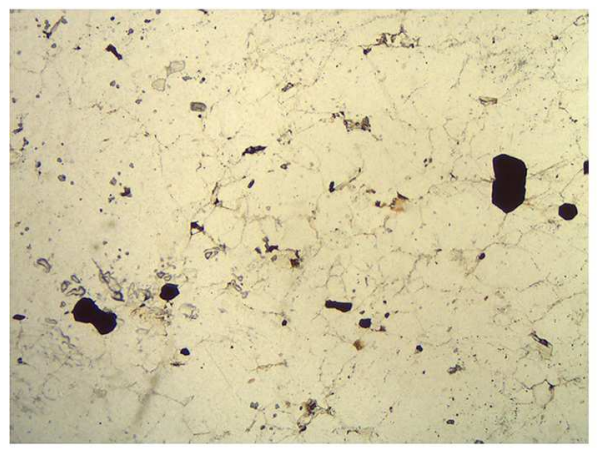

E

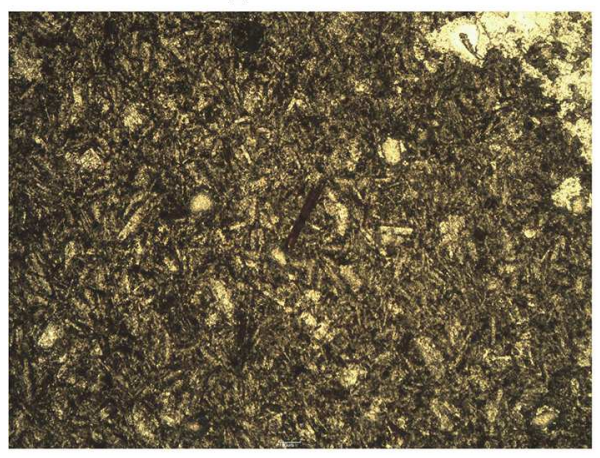

B

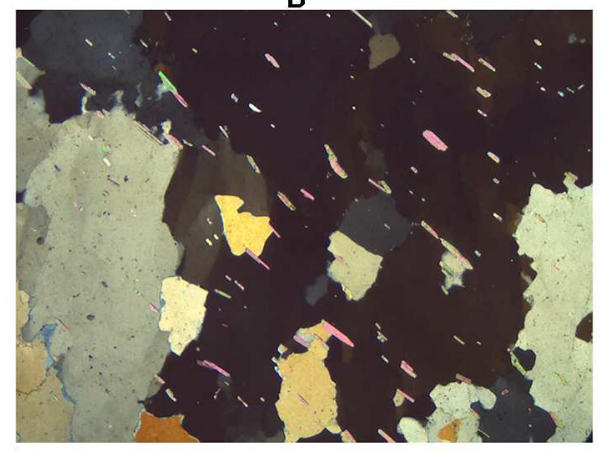

D

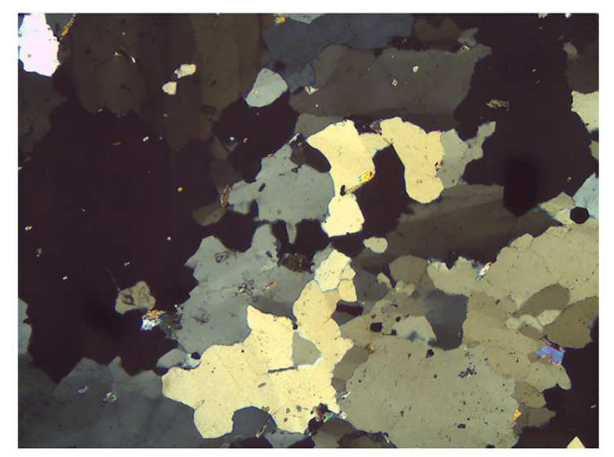

F

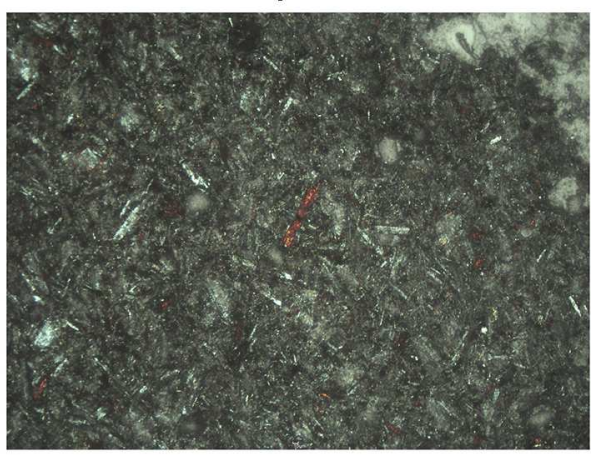

FIGURE 8 | Naisiusiu 14: (A) Quartz and muscovite (PPL 2x horizontal field width $1.1 \mathrm{~mm}$ ); (B) same as (A) quartz crystals show undulatory extinction and sutured boundaries (XP); Oittii 1A: (C) large idioblastic rutile crystals (PPL 2x horizontal field width $1.1 \mathrm{~mm}$ ); (D) same as (C) quartz crystals show undulatory extinction, and muscovite crystals are fragmented and have a random lineation (XP); A6: (E) kaersutite crystals included in a felty groundmass (PPL $4 \times$ horizontal field width $0.55 \mathrm{~mm}) ;(\mathbf{F})$ same as (E) note the distinctive red kaersutite crystals (XP).

This rock type can be found overlain by quartzite (Figure 7D; Supplementary Figures 34E,F).

One sample of nephelinite recovered on the surface of the outcrop contains nepheline, aegirine-augite, sanidine, and hornblende microphenocrysts included in a flow-aligned browngray groundmass with devitrified glass and minor amounts of oxides (Tables 2, 3). SEM-EDS and EPMA allowed the identification of potassium feldspar, secondary quartz, apatite, and ilmenite (Supplementary Figures 40, 41). This sample originates from Sadiman based on mineralogical similarities (Zaitsev et al., 2012).

\section{Oittii}

\section{Geology}

Oittii is a low-lying, quartzitic and schistic outcrop north of Naibor Soit Ndogo (Figure 1b). The metamorphosed outcrop contains east-west trending quartzites with foliation planes dipping north, north-south trending steeply-dipping quartzites, and east-west trending steeply-dipping mica schist with harmonic folding (Figures 7E,F; Supplementary Figure 42). The outcrop principally consists of coarse-grained gray quartzites that are highly oxidized, and large numbers of fragmented rocks suggest recent mining activities. 


\section{Petrography}

Previous studies have identified mica schist and quartzite but no petrographic descriptions are available (Leakey, 1965; Jones, 1994; Kyara, 1999). Accessory minerals present in coarse- to finegrained quartzites include muscovite, alkali feldspar, hematite, rutile, and plagioclase (Figures 8C,D; Supplementary Figure 43; Table 2; Supplementary Section 1.9). Quartz crystals occasionally have sutured boundaries. Muscovite crystals display a platy habit, are either interstitial to or included in quartz, and show a sub-parallel to random lineation. Rare hematite crystals are generally interstitial to quartz. The mineral assemblages are consistent with a sandstone protolith, but no relict sedimentary textures are preserved.

\section{Olbalbal}

\section{Geology}

Olbalbal is a fault graben located between Ngorongoro/Olmoti and Oldupai's First Fault (Figures 1b, 7G; Supplementary Figure 44), and was formed between 1.3 and $0.6 \mathrm{Ma}$ as a result of regional tilting and faulting events (Hay, 1976; Foster et al., 1997; Mollel and Swisher, 2012). Olbalbal may be considered as a temporally constrained secondary source of raw materials and is the present-day drainage sump of the Oldupai River and the northwestern NVH. Four magmatic samples recovered in secondary position were analyzed for this study (Table 1).

\section{Petrography}

Sample A1 is a nephelinite and contains nepheline phenocrysts and lesser amounts of aegirine-augite, hornblende, and titanite included in a dark-brown groundmass (Table 2) (Supplementary Section 1.10). The phenocrysts and groundmass are weakly aligned. SEM-EDS and EPMA analysis allowed the identification of titanoaugite, wollastonite, apatite, calcic plagioclase, and Cl-bearing silicates (Figure 6G; Supplementary Figures 45, 46). This sample can be sourced to Sadiman and would be categorized as Zaitsev et al.'s (2012) "Rock type II" based on the presence of wollastonite.

The non-diagnostic mineral assemblages for the three remaining samples (A2, A5A/B, and A6) hindered satisfactory classification (Table 2) (Supplementary Section 1.10). In these samples, oxides are common and together with the presence of secondary carbonate crystals are, in part, indicative of seasonal exposure to inundation regimes typical of Olbalbal (Supplementary Figure 44B).

Sample A2 is an inequigranular, flow-aligned, porphyritic basalt with plagioclase $(20 \%)$, opaque crystals (1\%), augite (1\%), and olivine (1\%) phenocrysts included in a trachytic lightgray plagioclase-rich groundmass. Plagioclase phenocrysts are occasionally zoned and have a glomerophyric texture. Olivine phenocrysts are occasionally altered evidenced by internal cracks filled with opaque material.

Sample A5A/B is a flow-aligned, porphyritic basalt with plagioclase $(1 \%)$ and augite $(<1 \%)$ phenocrysts included in a trachytic light-gray plagioclase-rich groundmass. Vesicles are occasionally filled with secondary micritic carbonate crystals that precipitated from seasonal standing water rather than having crystallized from molten-carbonate magma.

Sample A6 was identified as a trachyandesite/basalt from Olmoti based on the presence of kaersutite (Figures 8E,F; Supplementary Figure 47) (Mollel, 2002; Mollel et al., 2009). This sample is vesicular, felty, and contains plagioclase $(1 \%)$, kaersutite $(1 \%)$, augite $(<1 \%)$, alkali feldspar $(<1 \%)$, pyroxene $(<1 \%)$, ilmenite $(<1 \%)$, and magnetite $(<1 \%)$ microphenocrysts included in a felty light-gray groundmass. SEM-EDS and EPMA analysis confirmed the presence of kaersutite, potassium feldspar, pyroxene, ilmenite, and magnetite (Figure 6H; Supplementary Figures 48, 49).

There are a minimum of four varieties of igneous rocks that can be found at Olbalbal (Tables 2, 3), including phenocrystrich nephelinite sourced from Sadiman, two basaltic varieties with different amounts of plagioclase, and kaersutite-bearing trachyandesite/basalt sourced from Olmoti.

\section{INTER-OUTCROP COMPARATIVE ANALYSES OF QUARTZITES AND META-GRANITES}

Quartzites and meta-granites form the most abundant raw materials in the outcrops described in this study. These lithologies show variations in modal mineralogy and texture that may be used to group them into distinct varieties. The following sections describe the quartzite and meta-granite varieties deemed archaeologically relevant for sourcing.

\section{Quartzites}

From the 16 quartzite varieties, two co-occur at two outcrops (Tables 2, 4):

(1) Variety 8 from Naibor Soit Ndogo is a coarse-grained fuchsite-bearing quartzite. Similar modal percentages of quartz, muscovite, fuchsite, rutile, and opaque crystals can also be found at Naibor Soit Kubwa in Variety 6. The presence of fuchsite at both outcrops is unique compared to all sampled outcrops in the Oldupai paleobasin, while the presence of magnetite is unique to quartzite from Naibor Soit Kubwa. Samples classified in Variety 6 and 8 fall within our previously established Raw Material Group Green 1 (Soto et al., 2020a).

Six other quartzite varieties uniquely occur at an individual outcrop (Tables 2, 4):

(2) Variety 2 is a coarse-grained alkali feldspar-bearing quartzite from Endonyo Osunyai. The modal percentages of quartz $(\sim 80 \%)$ and alkali feldspar $(10-15 \%)$ are unique to this outcrop.

(3) Variety 5 is a coarse- to fine-grained muscovite-rich quartzite from Naibor Soit Kubwa. The modal percentages of quartz (70\%) and muscovite ( $230 \%)$ are unique to this outcrop.

(4) Variety 10 is a medium- to fine-grained quartzite from Naisiusiu. The polymineralic assemblage including biotite, Cr-bearing rutile, albite, and tschermakite are unique to this outcrop. 
TABLE 4 | Quartzite varieties.

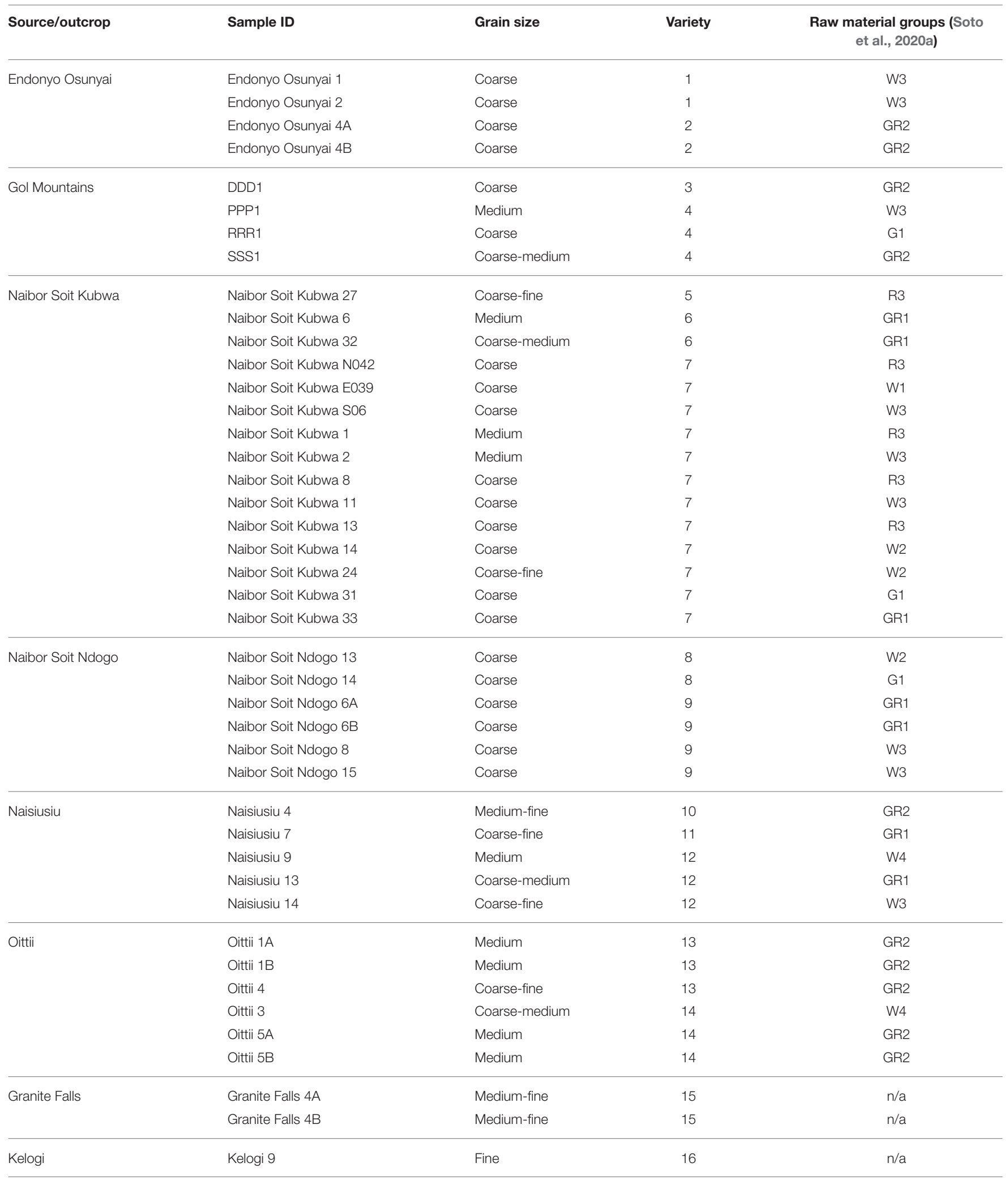

Refer to Table 2 for sample mineralogy. 

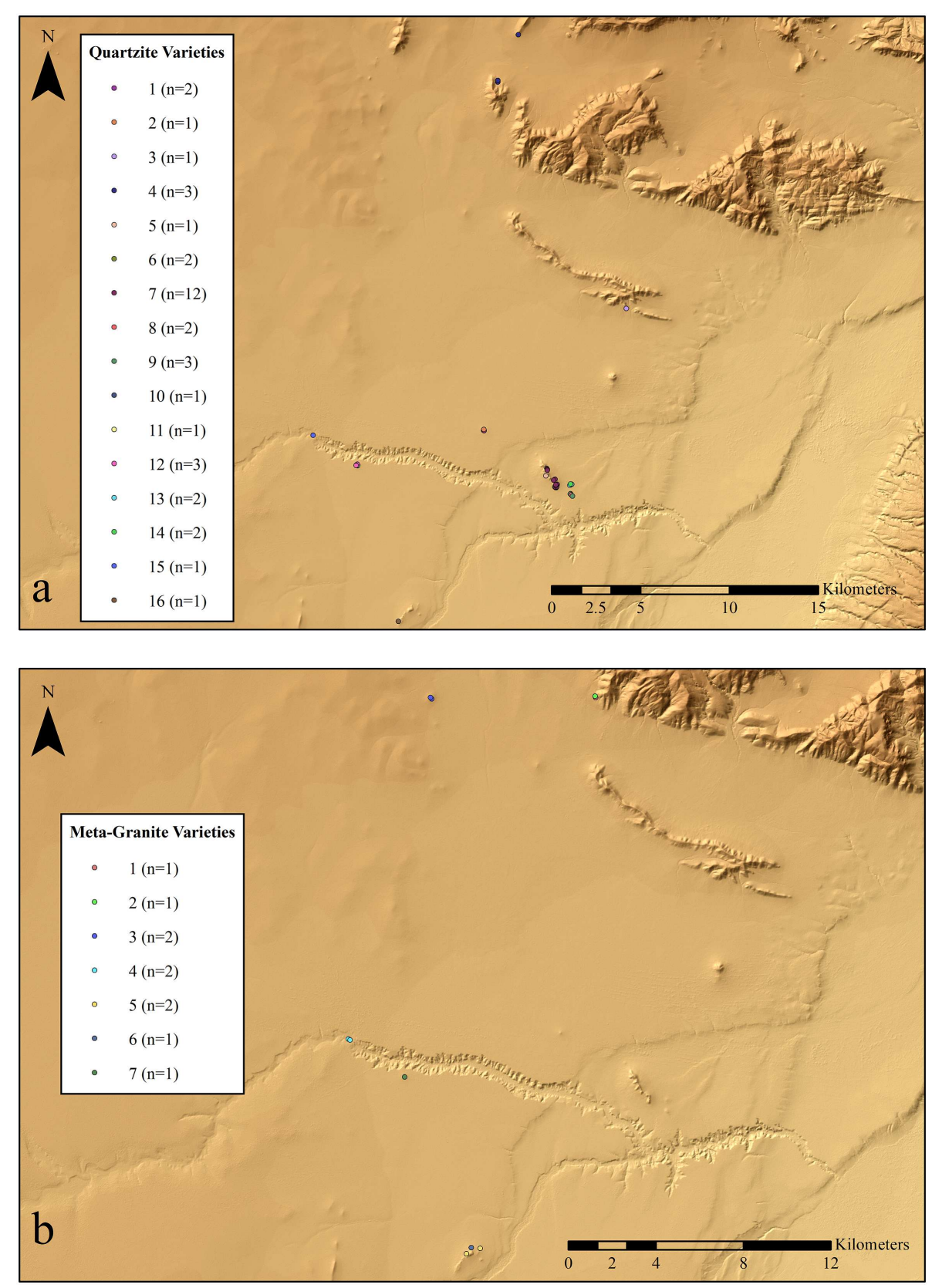

FIGURE 9 | (a) Intra-outcrop quartzite varieties in the Oldupai Gorge region. Refer to Figure $\mathbf{1 b}$ for outcrop names. Refer to section Quartzites. and Table $\mathbf{4}$ for additional details; (b) Intra-outcrop meta-granite varieties in the Oldupai Gorge region. Refer to Figure 1b for outcrop names. Refer to section Meta-Granites and Table 5 for additional details.

(5) Variety 11 is a coarse- to fine-grained quartzite from Naisiusiu. The polymineralic assemblage including chlorite, calcite, and glauconite are unique to this outcrop.

(6) Variety 14 is a coarse- to medium-grained alkali feldsparbearing quartzite from Oittii. The modal percentages of quartz (85\%), muscovite (10-15\%), and alkali feldspar $(\sim 1-$ $5 \%)$ are unique on a local scale. Similar modal percentages of quartz, muscovite, and alkali feldspar can also be found in Variety 3 from the Gol Mountains.
(7) Variety 16 is a fine-grained staurolite-kyanite-bearing quartzite that was found in secondary position at Kelogi (Tables 2, 4). The presence of staurolite and kyanite match published descriptions for quartzites from Endonyo Okule and Naisiusiu (Hay, 1976: Table 6) (Supplementary Table 4). Therefore, it may be inferred that this sample was transported in recent times to Kelogi from either Endonyo Okule or Naisiusiu (Figure 1b). 
Although quartzitic outcrops adjacent to Oldupai have similar mineral facies (Tables 2, 4), the results of this comparative analysis suggest that five outcrops contain six varieties of quartzites with unique mineral assemblages, and one pair of outcrops share fuchsitic quartzites (Figure 9a). The mineralogically defined petrographic varieties do not overlap with our previously established Raw Material Groups (Table 4) (cf. Soto et al., 2020a), which highlights the importance of systematic and multi-scalar characterization of reference collections to determine the potential source of lithics.

\section{Meta-Granites}

All seven intra-outcrop varieties are differentiable from one another (Tables 2, 5):

(1) Variety 1 is a medium-grained meta-monzo-granite from the Gol Mountains. The presence of rutile allows for its differentiation from Variety 2 which is from the same outcrop. The modal percentages of quartz (45\%), alkali feldspar (40\%), and the absence of muscovite and hornblende allow for its differentiation from all other varieties.

(2) Variety 2 is a medium- to fine-grained meta-quartz-rich granitoid from the Gol Mountains. The modal percentage of hornblende (6\%) relative to quartz (60\%) and alkali feldspar (20\%) allow for its differentiation from all other varieties.

(3) Variety 3 is a medium-to fine-grained meta-quartz-rich granitoid from the Gol Mountains. The modal percentages of quartz (70\%) and biotite (10\%) allow for its differentiation from all other varieties.

(4) Variety 4 is a medium- to fine-grained granite gneiss from Granite Falls. The modal percentages of muscovite (5-8\%) allow for its differentiation from all other varieties.

(5) Variety 5 is a medium-grained aegirine-bearing granite gneiss from Kelogi. The modal percentages of aegirine (20\%) and plagioclase (12-15\%) allow for its differentiation from Variety 6, also from Kelogi, and from all other varieties.

(6) Variety 6 is a medium- to fine-grained granite gneiss from Kelogi. The polyminerallic assemblage including titanite and zircon, and the modal percentages of plagioclase (25\%), quartz (25\%), and hornblende (20\%) allow for its differentiation from all other varieties.

(7) Variety 7 is a meta-syeno-granite from Naisiusiu. The modal percentages of opaque crystals $(7 \%)$, biotite $(2 \%)$, and hornblende (1\%) allow for its differentiation from all other varieties.

Despite the fact that meta-granitic outcrops in the greater Oldupai region have similar mineral facies (Tables 2, 5), the results of this comparative analysis reveal that five outcrops contain seven varieties with unique mineral assemblages (Figure 9b).

\section{ARCHAEOLOGICAL APPLICATIONS}

While not all known metamorphic, igneous, or sedimentary sources/outcrops have been characterized in this study (Figure 1b), inferences may be drawn concerning hominin raw
TABLE 5 | Meta-granite varieties.

\begin{tabular}{lllc}
\hline Source/outcrop & Sample ID & Grain size & Variety \\
\hline Gol & JJJ1 & Medium & 1 \\
Mountains & KKK1 & Medium-fine & 2 \\
& TIT1 & Fine & 3 \\
& UUU1 & Medium-fine & 3 \\
\hline Granite Falls & Granite Falls & Medium-fine & 4 \\
& 1A & Medium-fine & 4 \\
& Granite Falls & & \\
& 1B & Medium-fine & 4 \\
\hline Kelogi & Kranite Falls 2 & Medium & 5 \\
& Kelogi 1 & Medium & 5 \\
Kelogi 10 & Medium-fine & 6 \\
\hline Naisiusiu & Naisiusiu 3 & Medium-fine & 7 \\
\hline
\end{tabular}

Refer to Table 2 for sample mineralogy. JJJ1 and KKK1 are from the same outcrop. TI1 and UUU1 are from the same outcrop. Modes for Kelogi 1 and 3 are based on point counts instead of visual estimates.

material transport based on available macroscopic descriptions compared with our mineralogical data. Leakey (1994) noted the discovery of a single double-edged heavy-duty scraper on green quartzite from JK W within Bed III's fine-grained ferruginous sands. According to tabulated data for Bed II's HWK EE and EF-HR lithic assemblages, there are three (55.8 g) and two $(13.2 \mathrm{~g})$ lithics, respectively, manufactured from green quartzite (McHenry and de la Torre, 2018: Table 5). The green color of these artifacts most likely stem from the presence of fuchsite. Fuchsite is only present in quartzites from Naibor Soit Kubwa and/or Naibor Soit Ndogo (Variety 6/8) (Tables 2, 4) and therefore it may be inferred as the source/s where hominins procured green quartzite (Figure 10). This inference implies that fuchsite-bearing quartzitic outcrops were accessible at the time of hominin site occupation which correlates with basinwide paleogeographic trends for Bed II and III (Hay, 1976). Furthermore, it may be suggested that both Oldowan (HWK EE) and Acheulean (JK W and EF-HR) tool-making hominins, possibly of different biological taxa (but see de la Torre and Mora, 2014; Domínguez-Rodrigo et al., 2014), exploited the same outcrops at different times for raw materials.

The discovery of hornblende granofels lithologies recovered in secondary position south of Olongojoo (Figure 1b; Supplementary Figure 13A) (Table 1) is noteworthy as it implies that there are unmapped and/or buried granofelsic outcrops that may grade into the epidote-amphibolite facies in a similar fashion to Naibor Soit Kubwa (see section Naibor Soit Kubwa) and Isilale Aratum (Hay, 1976). This finding relates to Oldupai's archaeology as gabbroic rocks can metamorphose into hornblendic granofels (Bucher and Grapes, 2011). This may imply that the single "altered but unmetamorphosed" (Hay, 1976 , p. 185) gabbro artifact recovered from HWK in Lower 


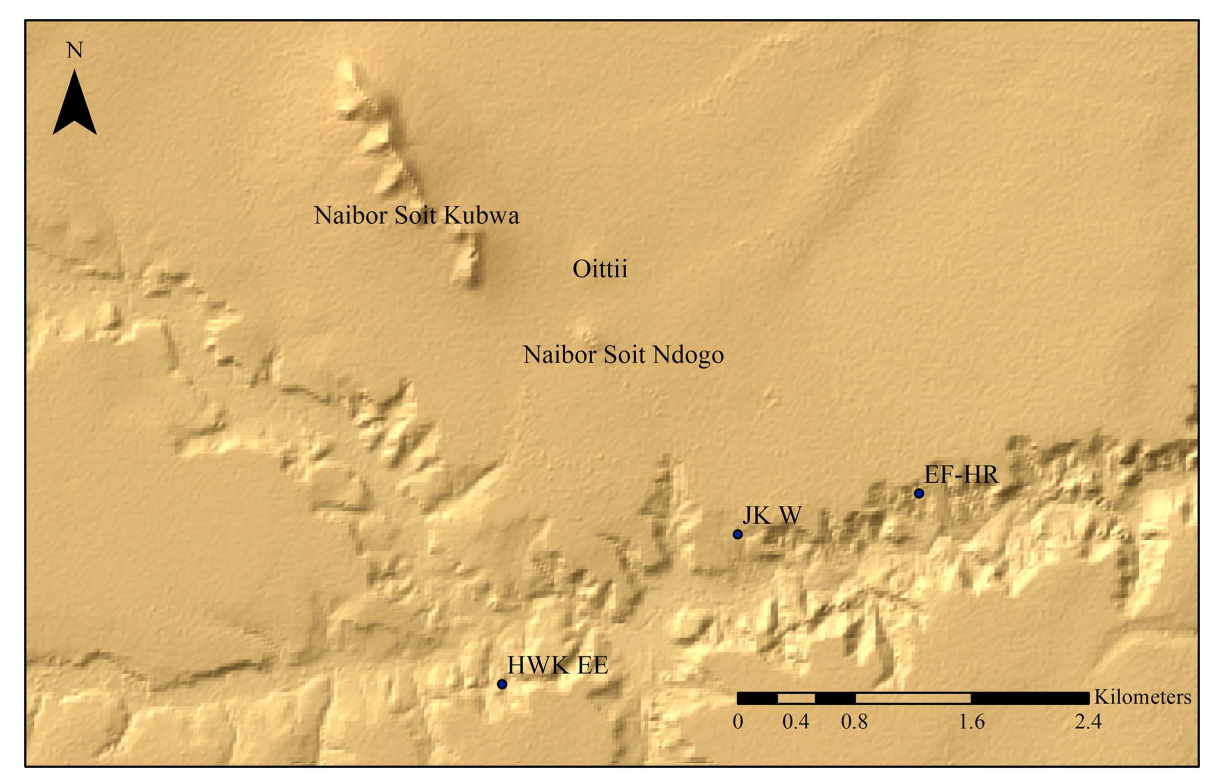

FIGURE 10 | Fuchsitic quartzites are unique to Naibor Soit Kubwa and Naibor Soit Ndogo (see Tables 2, 3). Therefore, it can be inferred that green quartzite artifacts from HWK EE (Oldowan) (McHenry and de la Torre, 2018: Table 5), as well as EF-HR and JK W (Acheulean) (Leakey, 1994; McHenry and de la Torre, 2018: Table 5) were sourced from Naibor Soit Kubwa and/or Naibor Soit Ndogo. Sites after Hay (1976).

Bed II may have been sourced from the Gol Mountains which are geographically closer to HWK than the Tanzania Craton (Figures 1a,b).

\section{CONCLUSIONS}

In this study, we synthesized existing descriptions with new petrographic data from several outcrops near Oldupai Gorge. By characterizing the range and variability of lithic raw materials that were available to Pleistocene hominins, we have demonstrated that there are unique mineralogical identifiers even among similar lithologies. More specifically, the comparative analyses of quartzites reveal as many as six distinguishable varieties with unique mineral assemblages, and two outcrops share fuchsitic quartzites (Variety 6/8). The identification of these mineralogically defined petrographic varieties (Table 4) through systematic analysis of our reference collection confirms that sourcing quartzite lithics from Oldupai may be best accomplished using a combination of techniques headlined by geochemical and petrographic testing (Soto et al., 2020a,b). For example, one quartzite sample recovered in secondary position at Kelogi has a mineral assemblage characterized by staurolite and kyanite. This sample's unique mineralogy (Figure 1b) matches published data for quartzites from Endonyo Okule and Naisiusiu (Hay, 1976: Table 6). The results of the comparative analysis among meta-granites reveal that five outcrops contain seven unique varieties. Although this study has been primarily focused on characterizing metamorphic lithologies, magmatic samples were also collected in primary positions at Engelosin, and in secondary positions at Granite Falls, Naisiusiu, and Olbalbal (Figure 1b) (Table 1).
These samples include phonolite, nephelinite, and basaltic rocks that are all distinguishable from each other based on mineralogy and texture (Tables 2, 3), and those recovered in secondary position may be sourced to their volcanic center by referencing previously published mineralogical data (Supplementary Table 4). Overall, our results suggest the feasibility of sourcing certain varieties of quartzites, metagranites, phonolites, nephelinites, and occasionally, basalts based on mineralogy. The unique mineralogy that serve to distinguish raw material sources may be reflected in the bulk chemical composition of these samples. Archaeological comparisons to our open-access reference collection can now be undertaken.

\section{DATA AVAILABILITY STATEMENT}

All datasets for this study are included in the article and the Supplementary Materials, and these can also be found at the Federated Research Data Repository (https://www.frdr.ca/repo/ handle/doi:10.20383/101.0185).

\section{AUTHOR'S NOTE}

A preprint of this article is available with the Open Science Framework (https://doi.org/10.31219/osf.io/s2vgr).

\section{AUTHOR CONTRIBUTIONS}

JF, MS, RN, PB, SC, PD, SH, and JM contributed to the conception, design, implementation, and funding of this study. JF, MS, JI, MI, FL, PL, AM, RP, and LT carried out field data 
collection. JF, MS, RN, CD, and RM analyzed the data. JF, MS, $\mathrm{RN}, \mathrm{PD}$, and JM wrote the manuscript. All authors revised the manuscript and approved the submitted version.

\section{FUNDING}

This work was supported by the Canadian Social Sciences and Humanities Research Council under its Partnership Grant Program no. 895-2016-1017.

\section{ACKNOWLEDGMENTS}

JF acknowledges that the datasets analyzed for this study and portions of this manuscript were originally presented in the form of a Master's Thesis at the University of Calgary (Favreau, 2019). These data can be accessed through the Federated Research Data Repository (doi: 10.20383/101.0153) and the Open Science Framework (doi: 10.31219/osf.io/ap8sh). The Tanzania Commission for Science and Technology authorized this

\section{REFERENCES}

Archer, W., and Braun, D. R. (2010). Variability in bifacial technology at elandsfontein, Western Cape, South Africa: a geometric morphometric approach. J. Archaeol. Sci. 37, 201-209. doi: 10.1016/j.jas.2009.09.033

Ashley, G. M., and Hay, R. L. (2002). "Sedimentation patterns in a Plio-Pleistocene volcaniclastic rift-platform basin, Olduvai Gorge, Tanzania," in Sedimentation in Continental Rifts, eds R. W. Renaut and G. M. Ashley (Tulsa: Society for Sedimentary Geology), 107-122.

Baker, B. H., Mohr, P. A., and Williams, L. A. J. (1972). Geology of the eastern rift system of Africa. Geol. Soc. Spec. Pap. 136, 1-68. doi: 10.1130/SPE136-p1

Bello-Alonso, P., Rios-Garaizar, J., Panera, J., Pérez-González, A., Rubio-Jara, S., Rojas-Mendoza, R., et al. (2020). A use-wear interpretation of the most common raw materials from the Olduvai Gorge: naibor soit quartzite. Quat. Int. 526, 169-192. doi: 10.1016/j.quaint.2019.09.025

Berry, P. A. (2012). Lake cycles and sediments: locality 80, Olduvai Gorge, Tanzania (Master's thesis). Georgia State University, Atlanta, GA, United States. Available online at: https://scholarworks.gsu.edu/geosciences_theses/47

Blomme, A., Degryse, P., Van Peer, P., and Elsen, J. (2012). The characterization of sedimentary quartzite artefacts from mesolithic sites, Belgium. Geol. Belg. 15, 193-199. Available online at: https://popups.uliege.be:443/1374-8505/ index.php?id=3690

Blumenschine, R. J., Masao, F. T., Tactikos, J. C., and Ebert, J. I. (2008). Effects of distance from stone source on landscape-scale variation in oldowan artifact assemblages in the Paleo-olduvai basin, Tanzania. J. Archaeol. Sci. 35, 76-86. doi: 10.1016/j.jas.2007.02.009

Blumenschine, R. J., Masao, F. T., Stollhofen, H., Stanistreet, I. G., Bamford, M. K., Albert, R. M., et al. (2012). Landscape distribution of Oldowan stone artifact assemblages across the fault compartments of the eastern Olduvai Lake Basin during early lowermost Bed II times. J. Hum. Evol. 63, 384-394. doi: 10.1016/j.jhevol.2011.05.003

Bucher, K., and Grapes, R. (2011). Petrogenesis of Metamorphic Rocks. Springer. Available Online at: https://link.springer.com/book/10.1007/978-3540-74169-5.

Byrne, F., Proffitt, T., Arroyo, A., and de la Torre, I. (2016). A comparative analysis of bipolar and freehand experimental knapping products from Olduvai Gorge, Tanzania. Quat. Int. 424, 58-68. doi: 10.1016/j.quaint.2015.08.018

Cahen, L., and Snelling, N. J. (1966). The Geochronology of Equatorial Africa. Amsterdam: North-Holland.

Cahen, L., Snelling, N. J., Delhal, J., Vail, J. R., Bonhomme, M., and Ledent, D. (1984). The Geochronology and Evolution of Africa. Oxford: Clarendon Press. work under permit no. 2018-112-NA-2018-36. The Tanzanian Ministry of Natural Resources and Tourism, through its Antiquities Division, granted permission to carry out this work (14/2017/2018). The Ngorongoro Conservation Area allowed us to enter the conservation area (BE.504/620/01/53). The export license for the materials presented herein was granted by both the Antiquities Division (EA.150/297/01: 5/2018/2019) and the Tanzanian Executive Secretary of the Mining Commission (00001258). The Stone Tools, Diet, and Sociality project recognizes the essential contributions of the Maasai community at Oldupai Gorge who was instrumental to this study. We thank the reviewers and Associate Editor whose feedback enhanced the quality of this manuscript.

\section{SUPPLEMENTARY MATERIAL}

The Supplementary Material for this article can be found online at: https://www.frontiersin.org/articles/10.3389/feart. 2020.00158/full\#supplementary-material

Cnudde, V., Dewanckele, J., De Kock, T., Boone, M., Baele, J.-M., Crombé, P., et al. (2013). Preliminary structural and chemical study of two quartzite varieties from the same geological formation: a first step in the sourcing of quartzites utilized during the Mesolithic in northwest Europe. Geol. Belg. 16, 27-34. Available online at: https://popups.uliege.be:443/1374-8505/index. php?id=3981

Courtenay, L. A., Yravedra, J., Aramendi, J., Maté-González, M. A., MartínPerea, D. M., Uribelarrea, D., et al. (2019). Cut marks and raw material exploitation in the lower pleistocene site of bell's korongo (BK, Olduvai Gorge, Tanzania): a geometric morphometric analysis. Quat. Int. 526, 155-168. doi: 10.1016/j.quaint.2019.06.018

Dalpra, C. L., and Pitblado, B. L. (2016). Discriminating quartzite sources petrographically in the upper gunnison basin, colorado: implications for paleoamerican lithic-procurement studies. PaleoAmerica 2, 22-31. doi: 10.1080/20555563.2015.1137684

Dawson, J. B. (1992). Neogene tectonics and volcanicity in the North Tanzania sector of the gregory rift valley: contrasts with the kenya sector. Tectonophysics 204, 81-92. doi: 10.1016/0040-1951(92)90271-7

Dawson, J. B. (2008). The Gregory Rift Valley and Neogene - Recent Volcanoes of Northern Tanzania. London: Geological Society Memoir No. 33.

de la Torre, I., Benito-Calvo, A., Arroyo, A., Zupancich, A., and Proffitt, T. (2013). Experimental protocols for the study of battered stone anvils from Olduvai Gorge (Tanzania). J. Archaeol. Sci. 40, 313-332. doi: 10.1016/j.jas.2012.08.007

de la Torre, I., and Mora, R. (2014). The transition to the acheulean in East Africa: an assessment of paradigms and evidence from Olduvai Gorge (Tanzania). J. Archaeol. Method Theory. 21, 781-823. doi: 10.1007/s10816-0139176-5

Deino, A. L. (2012). 40Ar/39Ar dating of Bed I, Olduvai Gorge, Tanzania, and the chronology of early Pleistocene climate change. J. Hum. Evol. 63, 251-273. doi: 10.1016/j.jhevol.2012.05.004

Diez-Martín, F., Sanchez Yustos, P., Domínguez-Rodrigo, M., Mabulla, A. Z. P., Bunn, H. T., Ashley, G. M., et al. (2010). New insights into hominin lithic activities at FLK North Bed I, Olduvai Gorge, Tanzania. Quat. Res. 74, 376-387. doi: 10.1016/j.yqres.2010.07.019

Diez-Martín, F., Sanchez, P., Domínguez-Rodrigo, M., Mabulla, A., and Barba, R. (2009). Were olduvai hominins making butchering tools or battering tools? Analysis of a recently excavated lithic assemblage from BK (Bed II, Olduvai Gorge, Tanzania). J. Anthropol. Archaeol. 28, 274-289. doi: 10.1016/j.jaa.2009.03.001

Diez-Martín, F., Yustos, P. S., Domínguez-Rodrigo, M., and Prendergast, M. E. (2011). An experimental study of bipolar and freehand knapping of 
Naibor Soit quartz from Olduvai Gorge (Tanzania). Am. Antiq. 76, 690-708. doi: 10.7183/0002-7316.76.4.690

Domínguez-Rodrigo, M., Diez-Martín, F., Mabulla, A., Baquedano, E., Bunn, H. T., and Musiba, C. (2014). The evolution of hominin behavior during the oldowan-acheulean transition: recent evidence from Olduvai Gorge and peninj (Tanzania). Quat. Int. 322-323, 1-6. doi: 10.1016/j.quaint.2014.01.017

Ebright, C. A. (1987). Quartzite petrography and its implications for prehistoric use archeological analysis. Archaeol. East. N. Am. 15, 29-45.

Egeland, C. P., Fadem, C. M., Byerly, R. M., Henderson, C., Fitzgerald, C., Mabulla, A. Z. P., et al. (2019). Geochemical and physical characterization of lithic raw materials in the olduvai basin, Tanzania. Quat. Int. 526, 99-115. doi: 10.1016/j.quaint.2019.09.036

Eren, M. I., Durant, A. J., Prendergast, M., and Mabulla, A. Z. P. (2014). Middle stone age archaeology at Olduvai Gorge, Tanzania. Quat. Int. 322-323, 292-313. doi: 10.1016/j.quaint.2013.12.042

Favreau, J. (2019). Lithic raw material characterisation at Olduvai Gorge, Tanzania (Master's thesis). University of Calgary, Calgary, AB, Canada. Available Online at: http://hdl.handle.net/1880/110186

Flannery, K. V. (1976). The Early Mesoamerican Village. London: Academic Press.

Foster, A., Ebinger, C., Mbede, E., and Rex, D. (1997). Tectonic development of the northern tanzanian sector of the East African rift system. J. Geol. Soc. London 154, 689-700. doi: 10.1144/gsigs.154. 4.0689

Fritz, H., Abdelsalam, M., Ali, K. A., Bingen, B., Collins, A. S., Fowler, A. R., et al. (2013). Orogen styles in the East African orogen: a review of the neoproterozoic to cambrian tectonic evolution. J. Afr. Earth Sci. 86, 65-106. doi: 10.1016/j.jafrearsci.2013.06.004

Gill, R. (2010). Igneous Rock and Processes: A Practical Guide. Chichester: WileyBlackwell.

Gurtov, A. N., and Eren, M. I. (2014). Lower paleolithic bipolar reduction and hominin selection of quartz at Olduvai Gorge, Tanzania: what's the connection? Quat. Int. 322-323, 285-291. doi: 10.1016/j.quaint.2013.08.010

Hay, R. L. (1968). Chert and its sodium-silicate precursors in sodiumcarbonate lakes of East Africa. Contrib. Mineral. Petrol. 17, 255-274. doi: $10.1007 / \mathrm{BF} 00380740$

Hay, R. L. (1971). "Geologic background of beds I and II: stratigraphic summary," in Olduvai Gorge Vol. 3: Excavations in Beds I and II, 1960-1963, ed M. D. Leakey (Cambridge: Cambridge University Press), 9-18.

Hay, R. L. (1973). Lithofacies and environments of bed I, Olduvai Gorge, Tanzania. Quat. Res. 3, 541-560. doi: 10.1016/0033-5894(73)90030-6

Hay, R. L. (1976). Geology of the Olduvai Gorge: A Study of Sedimentation in a Semiarid Basin. Berkeley: University of California Press.

Hay, R. L. (1990). “Olduvai Gorge: a case history in the interpretation of hominid paleoenvironments in East Africa," in Establishment of a Geologic Framework for Paleoanthropology, ed L. F. Laporte (Boulder, CO: Geological Society of America Special Paper 242), 23-37.

Hay, R. L., and Kyser, T. K. (2001). Chemical sedimentology and paleoenvironmental history of Lake Olduvai, a pliocene lake in northern Tanzania. Geol. Soc. Am. Bull. 113, 1505-1521. doi: 10.1130/0016-7606(2001)113<1505:CSAPHO > 2.0.CO;2

Jones, P. R. (1979). Effects of raw materials on biface manufacture. Science 204, 835-836. doi: 10.1126/science.204.4395.835

Jones, P. R. (1981). Experimental implement manufacture and use; a case study from Olduvai Gorge, Tanzania. Philos. Trans. Royal Soc. B 292, 189-195. doi: 10.1098/rstb.1981.0027

Jones, P. R. (1994). "Results of experimental work in relation to the stone industries of Olduvai Gorge," in Olduvai Gorge Volume 5: Excavations in Beds III, IV and the Masek Beds, 1968-1971, eds M. D. Leakey and D. A. Roe (Cambridge: Cambridge University Press), 254-298.

Kabete, J. M., Groves, D. I., McNaughton, N. J., and Mruma, A. H. (2012). A new tectonic and temporal framework for the Tanzanian shield: implications for gold metallogeny and undiscovered endowment. Ore Geol. Rev. 48, 88-124. doi: 10.1016/j.oregeorev.2012.02.009

Kent, P. (1978). Historical background: early exploration in the East African rift - the Gregory rift valley. J. Geol. Soc. London 6, 1-4. doi: 10.1144/GSL.SP.1978.006.01.02

Kimura, Y. (1997). The MNK chert factory site: the chert-using strategy by early hominids at Olduvai Gorge, Tanzania. Afr. Stud. Monogr. 18, 1-28.
Kyara, O. (1996). "Lithic raw materials as an epistemological tool for hominid behavioural reconstruction: a preliminary overview," in Aspects of African Archaeology: Papers From the Congress of the PanAfrican Association for Prehistory and Related Studies, ed G. Pwiti and R. Soper (Harare: University of Zimbabwe), 111-120.

Kyara, O. (1999). Lithic raw materials and their implications on assemblage variation and hominid behavior during bed II, Olduvai Gorge, Tanzania (Dissertation). Rutgers University, New Brunswick, NJ, United States.

Le Bas, M. J., and Streckeisen, A. L. (1991). The IUGS systematics of igneous rocks. J. Geol. Soc. London 148, 825-833. doi: 10.1144/gsigs.148.5.0825

Leakey, L. S. B. (1965). Olduvai Gorge, 1951-1961. Vol. 1: A Preliminary Report on the Geology and Fauna. Cambridge: Cambridge University Press.

Leakey, M. D. (1971). Olduvai Gorge Vol. 3: Excavations in Beds I and II, 1960-1963. Cambridge: Cambridge University Press.

Leakey, M. D. (1978). Olduvai Gorge 1911-75: a history of the investigations. J. Geol. Soc. London 6, 151-155. doi: 10.1144/GSL.SP.1978.006.01.12

Leakey, M. D. (1994). “Bed III Site JK (Juma’s Korongo)," in Olduvai Gorge Vol. 5: Excavations in Beds III, IV and the Masek Beds, 1968-1971, ed M. D. Leakey and D. A. Roe (Cambridge: Cambridge University Press), 15-35.

Leakey, M. D., Hay, R. L., Thurber, D. L., Protsch, R., and Berger, R. (1972). Stratigraphy, archaeology, and age of the ndutu and naisiusiu beds, Olduvai Gorge, Tanzania. World Archaeol. 3, 328-341. doi: 10.1080/00438243.1972.9979514

Leakey, M. D., and Roe, D. A. (1994). Olduvai Gorge Volume 5: Excavations in Beds III, IV and the Masek Beds, 1968-1971. Cambridge: Cambridge University Press.

Lebo, S. A., and Johnson, K. T. M. (2007). Geochemical sourcing of rock specimens and stone artifacts from Nihoa and Necker Islands, Hawai'i. J. Archaeol. Sci. 34, 858-871. doi: 10.1016/j.jas.2006.08.009

Mabulla, A. Z. P. (1990). Preliminary report on an archaeological survey of the ndutu beds, Olduvai Gorge, Tanzania. Nyame Akuma 33, 20-25.

Macgregor, D. (2015). History of the development of the East African Rift System: A series of interpreted maps through time. J. Afr. Earth Sci. 101, 232-252. doi: 10.1016/j.jafrearsci.2014.09.016

Manega, P. C. (1993). Geochronology, geochemistry and isotopic study of the pliopleistocene hominid sites and the ngorongoro volcanic highland in Northern Tanzania (Dissertation). University of Colorado Boulder, Boulder, CO, United States.

Mason, O. K., and Aigner, J. S. (1987). Petrographic analysis of basalt artifacts from three aleutian sites. Am. Antiq. 52, 595-607. doi: 10.2307/281601

McHenry, L. J., and de la Torre, I. (2018). Hominin raw material procurement in the oldowan-acheulean transition at Olduvai Gorge. J. Hum. Evol. 120, 378-401. doi: 10.1016/j.jhevol.2017.11.010

McHenry, L. J., Mollel, G. F., and Swisher, C. C. (2008). Compositional and textural correlations between Olduvai Gorge Bed I tephra and volcanic sources in the ngorongoro volcanic highlands, Tanzania. Quat. Int. 178, 306-319. doi: 10.1016/j.quaint.2007.01.004

Mehlman, M. J. (1977). Excavations at nasera rock, tanzania. Azania 12, 111-118. doi: 10.1080/00672707709511250

Mollel, G. F. (2002). Petrology and geochemistry of the southeastern ngorongoro volcanic highland; and contribution to "sourcing" of stone tools at Olduvai Gorge, Tanzania (Master's thesis). Rutgers University, New Brunswick, NJ, United States.

Mollel, G. F. (2007). Petrochemistry and geochronology of ngorongoro volcanic highland complex (NVHC) and its relationship to Laetoli and Olduvai Gorge, Tanzania (Dissertation). Rutgers University, New BrunswickM, NJ, United States.

Mollel, G. F., and Swisher, C. C. (2012). The ngorongoro volcanic highland and its relationships to volcanic deposits at Olduvai Gorge and east African rift volcanism. J. Hum. Evol. 63, 274-283. doi: 10.1016/j.jhevol.2011. 09.001

Mollel, G. F., Swisher, C. C., Feigenson, M. D., and Carr, M. J. (2008). Geochemical evolution of ngorongoro caldera, Northern Tanzania: implications for crust-magma interaction. Earth Planet. Sci. Lett. 271, 337-347. doi: 10.1016/j.epsl.2008.04.014

Mollel, G. F., Swisher, C. C., McHenry, L. J., Feigenson, M. D., and Carr, M. J. (2009). Petrogenesis of basalt-trachyte lavas from Olmoti Crater, Tanzania. J. Afr. Earth Sci. 54, 127-143. doi: 10.1016/j.jafrearsci.2009. 03.008 
Mora, R., and de la Torre, I. (2005). Percussion tools in olduvai beds I and II (Tanzania): implications for early human activities. J. Anthropol. Archaeol. 24, 179-192. doi: 10.1016/j.jaa.2004.12.001

O'Neil, J. R., and Hay, R. L. (1973). 18O/16O ratios in cherts associated with the saline lake deposits of East Africa. Earth Planet. Sci. Lett. 19, 257-266. doi: 10.1016/0012-821X(73)90126-X

Pickering, R. (1964). Endulen. Geological Survey of Tanzania Quarter Degree Sheet, 52 .

Pickering, R. (1965). Ngorongoro. Geological Survey of Tanzania Quarter Degree Sheet, 53.

Pitblado, B. L., Cannon, M. B., Neff, H., Dehler, C. M., and Nelson, S. T. (2013). LA-ICP-MS analysis of quartzite from the upper gunnison basin, Colorado. J. Archaeol. Sci. 40, 2196-2216. doi: 10.1016/j.jas.2012.11.016

Pitblado, B. L., Dehler, C., Neff, H., and Nelson, S. T. (2008). Pilot study experiments sourcing quartzite, gunnison basin, Colorado. Geoarchaeol. 23, 742-778. doi: 10.1002/gea.20240

Plummer, T. (2004). Flaked stones and old bones: biological and cultural evolution at the dawn of technology. Am. J. Phys. Anthropol. 47, 118-164. doi: 10.1002/ajpa.20157

Reimer, R. (2018). Lithic sourcing in Canada. Can. J. Archaeol. 42, 137-143.

Renfrew, C. (1975). "Trade as action at a distance," in Ancient Civilization and Trade, eds J. A. Sabloff and C. C. Lamberg-Karlovsky (Albuquerque: University of New Mexico Press), 3-60.

Reti, J. S. (2013). Methods for determining differential behaviors in stone tool production and application to the oldowan of Olduvai Gorge, Tanzania and Koobi Fora, Kenya (Dissertation). Rutgers University, New Brunswick, NJ, United States.

Santonja, M., Panera, J., Rubio-Jara, S., Pérez-González, A., Uribelarrea, D., Domínguez-Rodrigo, M., et al. (2014). Technological strategies and the economy of raw materials in the TK (Thiongo Korongo) lower occupation, bed II, Olduvai Gorge, Tanzania. Quat. Int. 322-323, 181-208. doi: 10.1016/j.quaint.2013.10.069

Scoon, R. N. (2018). Geology of National Parks of Central/Southern Kenya and Northern Tanzania. Cham: Springer.

Severin, K. P. (2004). Energy Dispersive Spectrometry of Common Rock Forming Minerals. Dordrecht: Kluwer Academic Publishers.

Shotton, F. W., and Hendry, G. L. (1979). The developing field of petrology in archaeology. J. Archaeol. Sci. 6, 75-84. doi: 10.1016/0305-4403(79)90034-7

Sidrys, R. V. (1976). Classic maya obsidian trade. Am. Antiq. 41, 449-464. doi: $10.2307 / 279011$

Soto, M., Favreau, J., Campeau, K., Carter, T., Abtosway, M., Bushozi, P. M., et al. (2020a). Fingerprinting of quartzitic outcrops at oldupai gorge, Tanzania. J. Archaeol. Sci. Rep. 29:102010. doi: 10.1016/j.jasrep.2019.102010

Soto, M., Favreau, J., Campeau, K., Carter, T., Durkin, P. D., Hubbard, S. M., et al. (2020b). Systematic sampling of quartzites in sourcing analysis: intra-outcrop variability at Naibor Soit, Tanzania (part I). Archaeol. Anthropol. Sci. 12:100. doi: 10.1007/s12520-020-01054-w

Stiles, D. (1991). Early hominid behaviour and culture tradition: raw material studies in bed II, Olduvai Gorge. Afr. Archaeol. Rev. 9, 1-19. doi: $10.1007 / \mathrm{BF} 01117214$

Stiles, D. (1998). "Raw material as evidence for human behaviour in the Lower Pleistocene: the Olduvai case," in Early Human Behaviour in Global Context: The Rise and Diversity of the Lower Palaeolithic Record, eds M. D. Petraglia and R. Korisettar (London: Routledge), 130-145.

Stiles, D. N., Hay, R. L., and O’Neil, J. R. (1974). The MNK chert factory site, Olduvai Gorge, Tanzania. World Archaeol. 5, 285-308. doi: 10.1080/00438243.1974.9979575
Stipp, M., Stünitz, H., Heilbronner, R., and Schmid, S. M. (2002). "Dynamic recrystallization of quartz: correlation between natural and experimental conditions," in Deformation Mechanisms, Rheology and Tectonics: Current Status and Future Perspectives, eds S. De Meer, M. R. Drury, J. H. P. De Bresser, and G. M. Pennock (London: Geological Society), 171-190.

Stout, D., Quade, J., Semaw, S., Rogers, M. J., and Levin, N. E. (2005). Raw material selectivity of the earliest stone toolmakers at Gona, Afar, Ethiopia. J. Hum. Evol. 48, 365-380. doi: 10.1016/j.jhevol.2004.10.006

Streckeisen, A. (1976). To each plutonic rock its proper name. Earth Sci. Rev. 12, 1-33. doi: 10.1016/0012-8252(76)90052-0

Stross, F. H., Hay, R. L., Asaro, F., Bowman, H. R., and Michel, H. V. (1988). Sources of the quartzite of some ancient Egyptian sculptures. Archaeometry 30, 109-119. doi: 10.1111/j.1475-4754.1988. tb00439.x

Tactikos, J. C. (2005). A landscape perspective on the oldowan from Olduvai Gorge, Tanzania (Dissertation). Rutgers University, New Brunswick, NJ, United States.

Terry, R. D., and Chilingar, G. V. (1955). Summary of "concerning some additional aids in studying sedimentary formations" by M. S. Shvetsov. J. Sediment. Petrol. 25, 229-234. doi: 10.1306/74D70466-2B21-11D7-8648000102 C1865D

Veldeman, I., Baele, J.-M., Goemaere, E., Deceukelaire, M., Dusar, M., and De Doncker, H. W. J. A. (2012). Characterizing the hypersiliceous rocks of Belgium used in (pre-) history: a case study on sourcing sedimentary quartzites. $J$. Geophys. Eng. 9, S118-S128. doi: 10.1088/1742-2132/9/4/S118

Weigand, P. C., Harbottle, G., and Sayre, E. V. (1977). "Turquoise sources and source analysis: Mesoamerica and the Southwestern USA," in Exchange Systems in Prehistory, eds T. K. Earle and J. E. Ericson (New York, NY: Academic Press), 15-34.

Yravedra, J., Maté-González, M. Á., Palomeque-González, J. F., Aramendi, J., Estaca-Gómez, V., San Juan Blazquez, M., et al. (2017). A new approach to raw material use in the exploitation of animal carcasses at BK (upper bed II, Olduvai Gorge, Tanzania): a micro-photogrammetric and geometric morphometric analysis of fossil cut marks. Boreas 46, 860-873. doi: 10.1111/ bor. 12224

Yustos, P. S., Diez-Martín, F., Díaz, I. M., Duque, J., Fraile, C., and Domínguez, M. (2015). Production and use of percussive stone tools in the early stone age: experimental approach to the lithic record of Olduvai Gorge, Tanzania. J. Archaeol. Sci. Rep. 2, 367-383. doi: 10.1016/j.jasrep.2015. 03.005

Zaitsev, A. N., Marks, M. A. W., Wenzel, T., Spratt, J., Sharygin, V. V., Strekopytov, S., et al. (2012). Mineralogy, geochemistry and petrology of the phonolitic to nephelinitic sadiman volcano, crater highlands, Tanzania. Lithos 152, 66-83. doi: 10.1016/j.lithos.2012.03.001

Conflict of Interest: The authors declare that the research was conducted in the absence of any commercial or financial relationships that could be construed as a potential conflict of interest.

Copyright (c) 2020 Favreau, Soto, Nair, Bushozi, Clarke, DeBuhr, Durkin, Hubbard, Inwood, Itambu, Larter, Lee, Marr, Mwambwiga, Patalano, Tucker and Mercader. This is an open-access article distributed under the terms of the Creative Commons Attribution License (CC BY). The use, distribution or reproduction in other forums is permitted, provided the original author(s) and the copyright owner(s) are credited and that the original publication in this journal is cited, in accordance with accepted academic practice. No use, distribution or reproduction is permitted which does not comply with these terms. 